\title{
El domador de pulgas de Max Jiménez: una aproximación a su pensamiento filosófico
}

Carla Arce

Escuela de Filosofía

Universidad Nacional

"Es bien difícil encontrar consuelo en la filosofía. Se queda uno de filósofo y sin consuelo.” Max Jiménez, Candelillas, 1978.

\section{Resumen}

El domador de pulgas (1936), novela de Max Jiménez Huete (1900-1947), escritor y artista plástico costarricense, representa la universalidad de su pensamiento en relación con su decepción de la humanidad. Jiménez, en esta obra, hace una simbolización fabulesca de la humanidad como resultado de la pérdida de valores de la sociedad.

Palabras clave: El domador de pulgas, novela costarricense, Max Jiménez Huete, existencialismo

\begin{abstract}
El domador de pulgas (The Flea Tames)(1936), a novel by Max Jiménez Huete (1900-1947), a Costa Rican writer and artist, represents the universality of his thought in relation to human disappointment. Jiménez makes a fictional symbolization of humanity as a result of the loss of social values.
\end{abstract}

Keywords: El domador de pulgas (The Flea Tames), Costa Rican novel, Max Jiménez Huete, existentialism 


\section{Breve acercamiento al existencialismo y su impacto en el pensamiento de Max Jiménez}

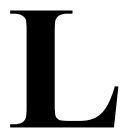

os acontecimientos, entre ellos las dos guerras mundiales, que durante principios del siglo XX marcaron el pensamiento de Max Jiménez, frente a la naturaleza humana y que contribuyeron, a su vez, a que se desarrollaran las filosofías existencialistas y las del absurdo, fueron el viaducto que hizo que filósofos y escritores a fuerza de buscar y describir los convencionalismos sociales, la degradación humana, la muerte, la invalidez de la razón ilustrada y nuestro estado de inautenticidad, se ampararan en las ideas que buscaban romper con la estabilidad lógica. Hay que advertir de las sombras que rodean lo humano, de la angustia, de las contradicciones internas propias de la humanidad, así como sus más íntimos miedos, y evitar así ello la simulación, los pretextos y el ataviado. Como expresa Ezequiel Estrada (1967): "esa nueva intuición, el funcionamiento de esos nuevos órganos mentales y sensitivos, que por simultánea visión bifocal han originado una nueva técnica de comprender y de intuir el mundo de las cosas y de la vida, se anunció con algunos hombres extraordinarios, casi coetáneos, Kierkegaard, Gauss, Poe" (22).

El existencialismo, como corriente filosófica, debe su popularidad al filósofo francés Jean-Paul Sartre. Aunque en esencia se perciba un fuerte déficit con aquellos precursores de esta corriente, especialmente con Kierkegaard, Heidegger y Nietzsche. Se debe aclarar, también, que es evidente que dicha corriente se separa de aquellos primeros preceptos, sobre todo con respecto a la concepción alemana, pues ni Heidegger ni Jaspers consideran la existencia como objeto de estudio; al contrario, consideran la existencia como una particularidad de ella misma, carente de organización y catalogación. Pero conserva uno de los rasgos más importantes de este movimiento, que según Abbagnano (1962), ${ }^{1}$ la hacen tan diferente de aquel ejercicio, distinguido solamente por "unos pocos espíritus ociosos" (13) y que nos interesa para este estudio: la existencia humana como el más importante de los temas filosóficos.

El ser humano es libertad, afirma el existencialismo, y como tal, elegir es una de sus consecuencias. La existencia es elección. Siendo esto así, no se puede abandonar el elegir; incluso no elegir implica una elección, no hay escape; no hay evasión, no se puede dejar de ser libre. La ontología que nos ofrece Sartre (1997) y que expone en su libro El Existencialismo es un Humanismo, es la ontología de lo concreto, esto es, el ser humano y no hay cabida para la abstracción ${ }^{2}$. El ser (diría Sartre) es esencialmente humano; en consecuencia, la nada y el ser convergen en esta esencia.

Por todo esto, se desprenden varias cosas que se deben asimilar en particular sobre el existencialismo francés: 1) El existencialismo, como tendencia filosófica que es, posee matices muy disímiles entre quienes se muestran seguidores o representantes

1 Filósofo italiano; uno de los tantos representantes del existencialismo.

2 No quiere decir que Sartre no estudiara la ontología como abstracción del Ser en cuanto Ser. De hecho inicia su estudio ontológico con esta rigurosidad. Estudio que se evidencia en su obra más completa El Ser y la Nada (1979). 
de esta corriente de pensamiento. De ahí su complejidad y el que no nos permitamos afirmar con simpleza que este movimiento es igual en Heidegger como en Kierkegaard, o decir que lo mismo es el existencialismo de Sartre que en Jaspers. Indudablemente el existencialismo maneja una serie de temas vitales, centrales; pero estos son tratados de manera diferente según el autor ${ }^{3}$. 2) Fue un movimiento filosófico que desde un principio (e independientemente del filósofo) buscó ser una forma alternativa a las oxidadas bases del pensamiento objetivante-científico. 3) No se debe considerar a Jean-Paul Sartre como el padre del existencialismo en el sentido estricto de la palabra. Francia, país donde se da la gestación y desarrollo de esta corriente es presa de un periodo doloroso y oscuro, la Segunda Guerra Mundial, y como tal, a la ocupación alemana en suelo francés, lo cual permitió que se dieran las condiciones necesarias para que se desarrollara el término existencialismo de signo francés. 4) La existencia es una empresa que involucra elecciones concretas dentro de la temporalidad. 5) El existencialismo afirma que el verdadero conocimiento se logra a partir de las vivencias humanas reales que permiten que el sujeto existente entienda y conozca la existencia. Ciertamente, los intelectuales como emisarios de esta corriente tenían un aviso importante que brindarle a la humanidad: que asumieran la vida, que se la permitieran apreciar desde cada particularidad subjetiva y que la enfrentáramos como parte de este mundo. Tal y como nos enseñó Kierkegaard.

3 Filosofía de la existencia en Alemania y cuyos mayores exponentes son Jaspers y Heidegger.
Pero lo que se quiere subrayar de lo anterior son dos cosas. Una tiene que ver, con el origen de la corriente existencialista de cuña francesa, porque el escritor Max Jiménez vivió en este país en el año 1922, y fue precisamente en ese año ${ }^{4}$ cuando empezó lo que llamaríamos "el despertar a su autenticidad". Durante su estadía en Francia comenzó a estudiar arte; para ese entonces, ya había abandonado su carrera de comercio y también las pretensiones paternas de dedicarse a los negocios de la familia. La segunda y última, discurre en el tema del ejercicio de nuestra libertad, sobre todo en la búsqueda por nuestra autenticidad, mermada entre tanta palabrería, discursos, teorías y pretextos.

Desde aquí podremos acercarnos al pensamiento vigente presente en la novela $E l D o-$ mador de Pulgas de Max Jiménez, novela costarricense pero de carácter universal que trata esencialmente sobre la inautenticidad en la que se encontraba la humanidad ante el panorama de tensiones y miedos producidos por los discursos totalitarios y la Primera Guerra Mundial. En el caso de América Latina, a raíz de las diatribas sobre nuestra identidad latinoamericana que debían ser reflejo del Viejo Continente, se anula lo que nos caracterizaba como pueblos. Se dará, sobre todo, énfasis, en el caso de Costa Rica, al discurso que divulgaba en esa época el sector oligárquico en el país, además, por su familiaridad.

Por ende, un rasgo presente en la novela de Jiménez es la insurrección de todos los valores que el autor muestra como

4 Aún no se tenía noción de quién era Jean-Paul Sartre, ya que este comienza su labor intelectual propiamente en el año 1929 cuando empieza a enseñar filosofía en los liceos Le Havre, Lion y Henri IV. 
resultado del desconcierto humano. Por lo cual nuestro escritor evidencia en su novela una simbolización fabulesca de la humanidad, como producto de la caída de los valores que La Ilustración defendió y que la razón no pudo resguardar más. Con motivo de lo anterior, nos apoyamos en el existencialismo francés ya que este buscó recuperar conciencia de que la libertad y la voluntad eran un todo en la comprensión de la existencia y que la época de idolatrar a la razón había pasado. Las atrocidades cometidas por la Segunda Guerra dejaban mucha tela que cortar con respecto a los juicios de la razón

\subsection{La novela}

La novela El Domador de Pulgas de Max Jiménez (1999), nos presenta el relato de un hombre, un domador de pulgas, que se entrega a un ideal: Brindar la libertad a sus amadas pulgas, emanciparlas con su sangre como un Cristo-redentor. Aquel tierno impulso terminaría por ahogarlo en un inmenso dolor al descubrir que aquellos pequeños seres que tanto anheló liberar de los prejuicios del circo, estaban comenzando a adoptar los vicios humanos, dejando atrás toda bondad e inocencia que las caracterizaba. La novela no presenta protagonistas, sino un cuadro de disímiles personajes "pulguientos", todos enfrentados a sus circunstancias. No se encuentra en esta novela un protagonista central o protagonistas pero sí un tema, que va ligando cada episodio.

La obra de Jiménez nos muestra, a partir del relato del domador, la angustia que este sufre al envolver a sus pulgas y entregarlas a un mundo adocenado. Luego de abandonar su animalidad inocente y tomar conciencia de su entorno, asumen y asimilan con esta nueva condición lo peor de los humanos, y muy poco de las virtudes que estos poseen.

Es a partir de un enfoque filosófico, especialmente de corte existencialista francés, que podemos acercarnos a un análisis de esta novela, inmensamente compleja en su propuesta; no intentaremos describir lo abstracta que puede ser en un inicio, pero es muy claro el mensaje que Jiménez deja ver entre líneas. Algunos cuadros de la novela se prestarán mejor para un análisis, como por ejemplo "el domador de pulgas", "el filósofo sexual y la pulga puta", "la pulga artista", "el caudillo y el temperamento ovejuno de la pulgas", entre otros. No obstante, se tratará de abordar la historia en su globalidad.

Por todo esto, la novela nos abre el camino para preguntarnos: ¿Nos escondemos en el dorso de nuestras máscaras, o se equivoca Max Jiménez? ¿Somos los humanos autenticidad, o todavía hoy cargamos con nuestra condición de apariencia, fruto de aquellos discursos dichos, o los no dichos, de las normas establecidas de la humanidad? ¿En un mundo que carece de sentido están nuestros mayores sacrificios e ideales huérfanos de juicio?

Ahora bien, para dar comienzo al presente análisis retendremos la novela El Domador de Pulgas. Nos limitaremos a mirarla desde una hermenéutica de la autenticidad y libertad. En primer lugar, se aborda el tema de la angustia y la redención en el punto llamado: El sentimiento de la angustia. Desde este apartado presentamos 
el sentimiento de dolor que experimenta el domador-libertador a raíz de su consagración y cómo a partir de este sentimiento, anhela una redención por su acto. En segundo lugar, la sección que lleva por nombre La autenticidad y la libertad versa sobre algunos personajes pulguientos en la novela que deben enfrentarse ante los demás desde su legitimidad. Luego, el estadio al que hemos denominado Libertarse, que alude al nombre de uno de los ensayos que publicó Max Jiménez para Repertorio Americano $^{5}$, donde se presenta una serie de cuadros (capítulos) donde Jiménez formula a partir de la ironía fuertes críticas al ideario costarricense.

Desde este análisis o tercer apartado, aseguramos retazos del contexto social que Jiménez vivió y que se confirma en su novlea.

\section{El sentimiento de la angustia}

Nos cuenta Albert Camus en su libro El Mito de Sísifo (1998), aludiendo a este singular personaje mitológico, que "no hay castigo más terrible que el trabajo inútil y sin esperanza" (129). Si comprendemos la premisa anterior como el sentido absurdo que rodea la existencia humana (como la entendieron Camus y Kafka), no nos será difícil adentrarnos en el "esfuerzo inútil" del cual es parte el domador. El sentimiento incierto que rodea a este, después de "liberar" a sus pulgas de su animalidad, es definido por Sartre como angustia. Esta

5 Álvaro Quesada Soto en su libro compilador Max Jiménez: obra literaria, en la página 67 de la edición 2004 de la Editorial de la Universidad de Costa Rica, nos presenta el ensayo Libertarse. En este, Jiménez nos presentó su compleja situación como artista en un medio conservador como la Costa Rica de principios del siglo XX. angustia, como la entendía el existencialismo francés, se refiere al sentimiento de responsabilidad, al grito de la conciencia de mi existencia, en tanto sujeto que ejerce la libertad. Conciencia de la libertad de nuestros actos. Entonces, en palabras de Sartre (1997):

Ante todo, ¿qué se entiende por angustia? El existencialista acostumbra a declarar que el hombre es angustia. Esto significa que el hombre que se compromete y que se da cuenta que sólo es lo que él ha elegido ser, es también un legislador, pues en su elección elige al mismo tiempo que a sí mismo a la humanidad entera, él no puede escapar al sentimiento de su total y profunda responsabilidad (44).

Esta sensación, esta angustia a la que se refiere Sartre, es el mismo estremecimiento que sufre el domador, es el sentido frente a la libertad de la decisión tomada.

Comenzaremos con el domador, pues este personaje es el preludio de la obra y la desgracia de las pulgas. La presencia de este personaje no es proporcional en toda la obra. Pero, es una figura esencial en la comprensión y análisis de la novela. Por parte de Jiménez, no hay una descripción precisa del personaje del domador, ni del espacio físico en el que se desarrollan los hechos de la obra. Sin embargo, se deja entrever que se trata de un hombre mayor. Trabaja para un circo y su padre había sido, también, un domador de pulgas.

Antes bien, debemos suponer que la ausencia de un espacio físico definido en la 
novela, responde a la necesidad de Max Jiménez (1999) de traspasar el tiempo y dejar a la libre el criterio del lector o la lectora, así como su imaginación. Como él mismo expresó en el prólogo a su libro El domador de pulgas: "los libros no son material fijo. Los libros mejoran o se descomponen con el tiempo. Libros de actualidad maravillosa, se van perdiendo en el horizonte de los años; otros son como resucitados que alimentan los siglos" (15). ${ }^{6}$

El domador, en un momento de entusiasmo altruista, decide que es tiempo de emancipar a sus pulgas de los prejuicios del circo. Decide ya no exponer a sus animalitos al espectáculo y entregarse por completo a ellos:

El domador decidió no exhibir más sus pulguitas, y vivir con ellas, repartirse con ellas. Darles la libertad dentro de su cuarto miserable, y seguir entregando su sangre para aquellos pobres seres brincones.

Había que redimir aquellos animalitos, víctimas de los dedos pulgares de las abuelas; había que libertar aquella raza, que había dado origen a tantas personalidades mal agradecidas, desde que se había inventado el sistema individual de matar pulgas (20).

Pero este acto absurdo se compara con la inutilidad del trabajo de Sísifo de cargar una piedra hasta la cima de una colina para luego volver a levantarla, sin ninguna recompensa. Termina hundiendo al

6 A partir de la presente edición solo se indicará la página correspondiente. domador en una angustia terrible. Aquel acto de libertad no hizo más que transformar a aquellos seres en seres perversos consumidos por su egoísmo, vicios y defectos.

Sin embargo, al principio, él no lo sabe. Se siente inspirado por una suerte de "impulso inicial". Al mismo tiempo, que aquel cuadro conmovedor de Cristo-Redentor lo anima.

Por la frente de aquel hombre corrió una gota de sudor. Y se parecía enormemente al padre de Jesús. Como un cuadro que él había visto en casa de su padre, que también había sido domador de pulgas. Había llegado a tener los ojos lánguidos de visiones muertas, y la barba como raíces descarnadas por la lluvia de los pesares.

El Padre, tenía en aquel cuadro el corazón en la mano. El domador alimentaba sus pulgas de la sangre de su brazo. Aquel corazón, como el brazo lleno de piquetes, seco, de piel como hoja de otoño, era la verdadera encarnación del amor (19).

Y como aquel Cristo-Redentor que dio su vida y sangre por los pecados de la humanidad, el domador, también, daría la suya por sus pulguitas. Virginia Trejos Montero (2006: s.p) en su ensayo Exploradores de la existencia. Max Jiménez Huete y su "Domador de pulgas", manifiesta lo absurdo del acto mismo de redimir del domador a sus pulguitas. "Absurdo. Absurdo ser mártir y absurdo ser redentor. ¿Liberador?” No obstante, este personaje, 
el domador-redentor, asume su realidad como señala Trejos, no la evade.

Es precisamente ahí donde da comienzo la angustia de este. La culpa y el arrepentimiento lo acompañarán en todo aquel proceso de redención. Son sensaciones, realidades interiores, que experimenta el domador frente a su decisión libre de redimir a sus pulgas. Esa angustia es a la que se refiere Sartre como aquella perceptibilidad que cualquier individuo asume frente a su elección dentro de una acción concreta; son, en el caso del domador de pulgas, las pruebas que lo colocan como sujeto libre.

¡Terrible!, sus pulgas, tan pulga una como la otra, ya no eran las mismas pulgas ¡qué diferencia!, antes organizadas por igual, del mismo principio, del mismo fin, ahora se estaban haciendo pulgas distintas. ¡Todo por su deseo de redimir pulgas! Ya su impulso estaba dado. Ahora él estaba pasando a espectador, nadie podría retornar ahora las pulgas a pulgas $(25,26)$.

Cada día que pasa se traduce en más sufrimiento para el domador. ¿Por qué había él buscado tanto el parecido con aquel cuadro de familia? En ese mismo sentido, afirmó Sartre (1997) que una "posibilidad solo tiene valor porque ha sido elegida" (47) y, con ella, el filósofo francés reiteró que una elección es valedera en tanto que un sujeto la elige como tal. "Cuando, por ejemplo, un jefe militar toma la responsabilidad de un ataque y envía un determinado número de hombres a la muerte, elige hacerlo y elige él solo" (46).
El domador eligió, y lo hizo en el rincón de su soledad. Entre una serie de opciones, él decidió emancipar a aquellos seres. Un acto de amor y sacrificio. Sin embargo, este ideal, este acto de elección se habría de deshacer. Al mismo tiempo que en el domador, su vida se iría agravando como consecuencia de convertirse en espectador de las adversidades en las que él implicó a sus pulgas. "El domador de pulgas se estaba quedando sin barba, porque se la jalaba, el sistema nervioso se le había descontrolado y se tiraba pelo por pelo, ya se había arrancado media barba. Tenía mucho miedo de volverse loco" (41). Este espectáculo que le ofrecían sus pulgas y el cual, él ayudó a formar, solo conseguía sumergirlo cada día en un sufrimiento mayor: la culpa.

Kierkegaard (1982) decía que "Cuanto, más alto asciende el individuo, tanto más caro ha de comprar todo, y para salvar el orden surge con lo absoluto de la libertad otra figura: La culpa" (131). Para el narrador omnisciente, el domador pasó de ser considerado culpable a ser, en definitiva, culpable. Jiménez así lo describe: “¡Qué culpable era! ¿Por qué había él buscado tanto el parecido con aquel cuadro de familiar? El padre de las barbas largas, el padre del hijo, de rayos sobre la cabeza y de paloma..." (26).

En su libertad de elección, el domador proyecta una serie de posibilidades y entre ellas escoge la culpa. En el siguiente párrafo el escritor costarricense nos plasma el terrible cuadro de angustia en que se encuentra el domador, su impotencia, su miserable estado físico, el sentimiento de asesino "artificial" por haber complicado la vida de unas inocentes criaturas. 
El domador se había arrinconado en uno de los cuatro ángulos de su cuarto, miserablemente se iba terminando ante lo que él llamaba los desacatos de las pulgas; sentía por momentos dentro de su cuerpo lo que debe sentir el asesino artificial, porque el que es criminal no siente nada, porque es así, lo interesante en la vida es volverse algo. La metamorfosis del espíritu es lo que da los renuevos, el domador se sentía criminal por haber impulsado a aquellos animalitos a las complicaciones de la vida. Algunas pulgas que todavía quedaban pulgas, le iban extrayendo poco a poco la sangre que le quedaba, cada día se marcaba más en el domador la fisonomía de un Cristo, él no sudaba sangre, pero se la sacaban (63).

Este hombre, que se tiró a redimir pulgas con el único fin de emanciparlas de prejuicios del circo, es ahora presa de una serie de sentimientos que abarcan culpa, miedo y arrepentimiento. Postergado en un rincón de su cuarto, medita sobre su sacrificio y extraña los días con aquellos inocentes y pequeños animalitos. Pero no hay retorno, deberá conformarse con ser testigo taciturno de las atrocidades las cuales sus pulgas han contribuido a formar. Deberá atestiguar cómo poco a poco, aquellas afables pulguitas van abandonando su animalidad por las sórdidas conductas y costumbres humanas.

Pero este lacrimoso personaje, a pesar de ser certificador constante de un intolerante espectáculo, causado por su intento de redención, da un paso cualitativo, es decir, no huye de su responsabilidad, a pesar de que el miedo, la culpa y el arrepentimiento lo embargan. Él asume su libertad y, con ella, sus consecuencias. No rehúye la realidad que construyó. "Sufre la angustia de una existencia sin esperanza" como afirma Trejos Montero (2006: s.p). El que manifieste todo este sentimiento de arrepentimiento, no lo libra de su culpa y, él lo sabe. No lo hará libre. "El individuo puede arrepentirse de su ira, y cuanto más profundo es, tanto más profundo es el arrepentimiento. Pero el arrepentimiento no puede hacerle libre; en esto fracasa" (Kierkegaard, 1982:140). El domador mira con horror y sufre. Es lo único que puede hacer ahora, ya que sus pulgas jamás volverán a ser las de antes. Su mundo, un cuartucho miserable, es destruido, consumido por sus propias criaturas.

Interesa reflexionar sobre este afligido antihéroe; sobre lo particular y universal que él ostenta. Primero se advierte lo que nos señala Virginia Trejos Montero (2006) sobre Max Jiménez cuando dice: "La obra de Max Jiménez no es simplemente una crítica a lo absurdo de la realidad vivida por el autor ni una evasión a su angustia; es un absurdo en sí misma. Sátira, ironía. No es producto de un sueño sino de una forma de ver la vida; de una forma de concebir la existencia del ser humano" (s.p). Lo más importante de la afirmación anterior es subrayar lo que se refiere a "una forma de concebir la existencia del ser humano".

Porque, según Trejos Montero, los escritores hacen de su vida una experiencia universal. A partir de sus personajes o historias se explora la vida, la muerte, el engaño, el dolor, la angustia, la libertad y demás circunstancias humanas. Cervantes 
al escribir su Quijote, debió sentir la necesidad de explorar algo en la existencia humana y captarla en su magnánima obra y compartirla con los demás. No se puede dudar en afianzar lo mismo en Max Jiménez: el domador no es un personaje elegido al azar, es representativo.

Probablemente el domador tiene más de Jiménez de lo que imaginamos como lectores. Este domador-libertador nos presenta una forma de mirar la existencia humana, en particular ciertos comportamientos humanos. En la introducción a este trabajo se dijo de Max Jiménez que padecía de disconformidad frente a lo establecido, de su voluntad reflexiva y contestataria. Por consiguiente, cuando al principio se dice que el domador ostentaba lo particular y, a la vez, lo universal, no era gratuito. Este personaje realiza un acto concreto dentro de la novela: liberar a sus pulgas a partir de la redención, pero fuera del ámbito literario, el domador se parece en ocasiones a muchos de nosotros ¿En cuántas ocasiones hemos intentado acaso redimir o redimirnos?

Max Jiménez decide que su domador redentor-libertador fracasará, precisamente, porque él no ve que haya esperanza alguna para la humanidad. Él mismo escribió con respecto al futuro, en su ensayo Del porvenir, que este estaba formado "a base de temores". "La misma esperanza tiene en sí gran cantidad de miedo: es ambición incierta" (Citado por Quesada, 2004:65).

En cuanto a la alegoría que utiliza Jiménez, domador-Cristo-Redentor y pulgashumanidad, debe llamarnos la atención, sobre todo, el aspecto desmitificador que subyace en el intento de redimir. En otras palabras, el fracaso que significa albergar esperanza alguna en la humanidad. El mismo Cristo-Redentor da su vida por la humanidad, y esta en ocasiones olvida el valor de ese sacrificio; los humanos repiten una y otra vez los mismos errores que llevaron a Jesús hasta la cruz. Este mismo desencanto por la humanidad, Jiménez, lo manifiesta en toda su obra narrativa. Al respecto afirma Quesada Soto en su artículo La narrativa de Max Jiménez: metáforas de la enajenación (1999):

En los textos narrativos de Max Jiménez el orden social aparece como un mecanismo regido por un poder arbitrario, por una racionalidad "mecánica", que sujeta o encadena a los seres humanos a su propio sentido, enajena su inteligencia o su voluntad y los constriñe a desempeñar un papel o a seguir patrones de comportamiento que los deshumaniza, los despoja de sus rasgos propiamente humanos, para asemejarlos a fantoches, insectos o bestias: seres enajenados, deformes y grotescos (28).

Hemos introducido este párrafo con la firme intención de rectificar junto con Quesada y evidenciar con Jiménez, que el arte, en este caso la novela El Domador de Pulgas, es eficaz herramienta para comunicar o resaltar lo contradictorio de la existencia, entre lo que parece ser y lo que es. Además, veamos cómo magníficamente Quesada habla sobre la racionalidad "mecánica" que abunda en los textos de Jiménez. Ese poder arbitrario que, según Quesada, enajena la voluntad de los individuos "y los constriñe a desempeñar 
un papel o a seguir patrones de comportamiento que los deshumaniza... es lo que evidenciamos con los personajes de la novela, son seres cuyo poder "mecánico" (el orden social establecido) los despoja de su identidad. Responden a patrones establecidos, como aquellas pulgas que juzgan y apartan a la pulga artista y a la pulga puta, hasta llegar al punto de deshumanizarlas.

No pretendemos aseverar aquí cuál fue el fin de esta novela para el escritor, pero no es casualidad que siendo Jiménez un sujeto que sobrellevó las consecuencias que acarreó la Primera Guerra Mundial, así como la crisis de 1929, constatara de paso las atrocidades humanas, lo frágiles que somos a causa de nuestra inautenticidad ante los discursos opresores, nuestra condición de esclavos frente a las máquinas y lo fácilmente quebrantables que somos ante los vicios. Naturalmente, como costarricense y ciudadano de Costa Rica de principios del siglo XX, Jiménez plantea por medio del domador y sus pulgas una crítica no solo a la humanidad entera, sino también a sus coterráneos, que parecían legitimar con su subordinación el discurso enajenante de la oligarquía cafetalera, contribuyendo así a gestar el estado de inautenticidad en los y las costarricenses del siglo anterior.

El discurso literario y la educación de aquel entonces, también servían como medios legitimadores que buscaban el orden social de las masas que el patriarcado tanto requería. Por lo tanto, todo este lenguaje confuso e idealizado asiste únicamente a crear esclavos al servicio de un discurso. Por lo cual, estas pulgas-hombres víctimas del intento del domador por redimirlas de su inocencia-animal y que, a partir de beber la sangre de un humano, absorben los más soeces vicios humanos, demuestran (y consideramos que es la intención del autor) la inferioridad de la humanidad al buscar compararla con insectos.

Es el intento por parte de Jiménez de colocarnos en una situación de inferioridad; esto es, a partir de esta metáfora literaria (hombres-pulgas), Jiménez sugiere la imposibilidad absurda de pretender esperar algo auténtico y puro del género humano; más bien este, a falta de legitimidad, contribuye a realizar atrocidades hacia los demás y hacia ellos mismos. Así pues, la novela El domador de pulgas es una reflexión en cuadros literarios que clama por el reconocimiento de nuestra humanidad imperfecta, reconociendo lo débiles que somos ante los embates de la vida. La novela busca avivar la duda. Como herramienta para nuestro despertar, solo en la sospecha comienza nuestra individualidad al asumir su subjetividad. De ahí que la verdadera y quizá la única redención comienza en nosotros mismos. Aunque quizá, no siempre sea así.

\subsection{La muerte del domador-redentor}

La muerte del redentor se describe en el apartado El Sabio y este es uno de los capítulos más intensos de esta novela, no solo por lo fuerte de las imágenes, sino porque patentiza la frustración de la redención. Este después del "acto de amor", nos referimos al acto de redimir, para con sus pulgas ahora irreconocibles para el domador, llevaba una vida petrificada, estática; fruto de la apetencia de las pulgas. 
El domador era ya como una máscara de cartón, de color amarillo verdoso, las pupilas muy negras como dos pozos inmensos, y en la visión parecía guardar el terror de los que mueren asesinados, que conservan una copia en los ojos del trágico momento.

El domador ignoraba cuántos años llevaba de existencia, lo habían secado tanto las pulgas que vivía con vida de árbol que ha sombreado siglos y siglos (121).

El párrafo anterior detalla el estado de indigencia en el que se encuentra el domador-redentor. "Era ya como una máscara de cartón", nos advierte el narrador omnisciente y, con esto, que en el rostro del aquel domador ya no se percibe ni una sola expresión. Él mismo ya ni se reconoce en el tiempo transcurrido, desde el día en que decidió redimir a las pulgas. Su vida es como la de un árbol, "que ha sombreado siglos y siglos"; está inmóvil y firme a pesar de los años sin embargo, nuestro domador está muriendo y él lo sabe.

Un día, los días son asunto personal, un día muy importante para el domador, porque sintió que se le terminaba la vida, con un resto de fuerzas se asomó a la ventanilla quitando las telarañas y el polvo. Y dio unos gritos, como podrían ser los gritos que se han acumulado durante siglos; a uno de los temerosos transeúntes le pareció que aquel desgraciado entre sus alaridos pedía un médico. Los periódicos llenaron sus páginas; se hablaba por lo bajo, con el temor de lo que pudieran oír los fantasmas que no vemos, y corrió la voz de que el domador quería un médico.

Los señores galenos no parecían decidirse, hasta que un verdadero científico, un sabio, de barba muy larga, y cabeza cana, con mil trabajos y crujir de maderas antiquísimas, llegó hasta el domador de pulgas.

Debe advertirse que los sabios son menos miedosos que el resto de los hombres, especialmente si están acostumbrados a tratar con la física, que pide explicaciones naturales (122).

Valga la extensión del párrafo, pero es necesario, dadas las circunstancias a las que nos enfrentamos para comprender a este personaje y lo que significa dentro de la novela.

Para el domador-redentor ha llegado la hora de encarar la muerte. Con ella, finalizará la angustiosa existencia. El domador grita y ese potente grito es interpretado por un transeúnte como una vociferación de auxilio, "y corrió la voz de que el domador quería un médico" (122). Pero, ¿era aquel grito una señal de pedir ayuda?, o ¿simplemente un dolor acumulado por años, hecho expresión? Las respuestas van y vienen a estas interrogantes. Sin embargo, interesa repasar algunos aspectos de este personaje.

El domador sabe que su "ser-en-el-mundo" está por finalizar. El domador está condenado a morir, no por su intento de redención, sino como individuo entregado a y sujeto a la existencia. 
El domador no huyó de la angustia, ni se refugió en la creencia de que su situación se debía a una serie de circunstancias ajenas a él y fuera de su control. En su, quizá, último momento de vida, sabe que al haber elegido $\mathrm{y}$, otorgándole a sus actos las exigencias necesarias, con las implicaciones que esto significa, él se eligió con estas decisiones o elecciones, a sí mismo: un redentor. En su propia angustia, el domador, se percibe como posibilidad, en situación consigo mismo. Nunca con respecto a otros. Es decir, no como una mera eventualidad con respecto a los otros sujetos existentes. Jamás culpó a terceros por su error de llevar a unas inocentes criaturas, las pulgas, a un mundo lleno se prejuicios y vicios. Él golpeó su pecho con sus propias manos dentro de las cuatro paredes que lo albergaban.

Lo anterior sirve como propósito para describir el estado en que se encontraba el domador antes de su muerte, mucho antes de esta. Y, de paso, afirmar que el grito que el andariego le escucha propinar al domador es un grito de júbilo por el desenlace que se aproxima y, quizá con el su redención. Pero nada más lejos se encontraba de esta ilusión. Lo que se acerca, para el domador-redentor, era el enjuiciamiento por parte de una de aquellos seres que él, por amor, intentó redimir.

Toda redención busca rescatar y liberar, poder obtener el perdón por viejos pecados. El domador buscó la redención para sus pulgas; estas, ya no serían el "hazmerreír de las ferias". Se acabarían los prejuicios hacia estos animalitos. "El cinematógrafo las había tomado en una forma burlesca: se escapaban las pulgas, la gente desde luego se rascaba y se hacía chiste de unos animales que honradamente lo único que buscaban era su alimentación” $(19,20)$.

Por lo tanto, y visto que la novela $E l d o-$ mador de pulgas, es un texto en el cual el escritor Max Jiménez plantea un llamado de exhortación a partir de la metáfora hombres-pulgas, para que despertemos del sopor en el que nos mantienen los convencionalismos, normas, estereotipos, discursos morales religiosos impuestos y demás mentiras sociales, se afirmaría desde esta línea qué es la tan ansiada redención que busca la novela El domador de pulgas. Liberarnos de prejuicios, de discursos impuestos, de todo aquello que no permite que seamos nosotros mismos o nosotras mismas. Aquellas mentiras sociales que pretenden que vivamos en un estado de inercia mental.

Habló el sabio:

—Usted es el domador de pulgas, usted es el que se metió a redimir pulgas, usted porque daba su sangre tuvo la osadía de sentirse un redentor, fue usted el que lanzó a unas humildes pulgas, que eran felices, a la misma miseria de la humanidad.

El sabio se pasaba la mano por la cara como si fuera una pata.

-Usted miserable, _continuaba el sabio-, convirtió un mundo tranquilo, que lo único que hacía era procurarse la vida, y para quienes la vida, por esa simple razón, tenía especial e inmensa importancia, al 
más amargo e insondable de los precipicios. Tal vez usted aquí dentro de su encierro cobarde, no sepa que el mundo de las pulgas, actualmente se asesina y se denigra, por ambición de mando y por dinero, que también lleva en sí el deseo de mandar. Casi no existe pulga que se haya medio instruido, que no tenga ambición política, pulgas que siendo igual o muy parecidas a las otras pulgas, viven con la desesperación de gobernar. Ese terrible vicio del mundo, sostenido entre calumnias y crímenes.

Ya el sabio daba unos brincos terribles impulsado por las piernas $(122,123)$.

Vemos en esta escena que el domador-redentor es amenazado por una de esas pulgas, que él intentó liberar de prejuicios. Ahora, más bien, lo desprecian. La pulga-sabio le reprocha el haber arrojado a las pulgas a la misma condición tan miserable en la que conviven casi a diario los humanos.

El mundo pulguiento, que creó el domador a partir de su sangre y que perseguía la exoneración de las pulgas, es, al mismo tiempo, el miserable mundo de los humanos. Jiménez evidencia con la analogía (hombres-pulgas) que está convencido de que en este mundo no hay tal redención, porque el ser humano es desconocedor de su libertad. Día a día, el género humano es portador de prejuicios y repite conductas desagradables. Le temen al vértigo que representa la constante reflexión. Difícilmente, irrumpen en sus propios pensamientos. Algunos prefieren no desdoblar sus días y sus noches en la introspección de sus ideas. Y prefieren que sean otros los que les digan cómo pensar y sentir.

En un mundo así, no existe la redención. ¿Cómo podría? Si se ha convertido "en un fracaso" y aun queriendo cambiarlo, "no se puede volver atrás" dice Jiménez.

El domador aterrado decía:

—Un Redentor...un Redentor...

El sabio fuera de sí continuó:

- ¿Un Redentor? Miserable, no ha sido eso lo que usted ha hecho, no sabe usted que el mundo por las miserias humanas se ha convertido en un fracaso, y que aun confesándolo y reconociéndolo, no se puede volver atrás; no sabe usted que las ideas siguen rodando y que de nebulosas se convierten en mundos.

No sabe usted que se vive para arrebatarse las cosas, y que las pulgas mejores tienen que resignarse a pasar la vida solamente para comer y mantener una familia, ya que el espíritu no cuenta, y que se aumentan más y más la miseria y las necesidades, dentro del adelanto, dentro del llamado progreso, dentro de mayor producción la gente se muere de hambre. $(123,124)$

Finalmente, debemos reconocer, en este estremecedor final, lo que estos dos personajes nos dicen entre líneas. Por un lado, tenemos al sabio, quien revela su verdadera identidad. Él es una pulga-hombre y no siente más que resentimiento y odio hacia su libertador. "Usted porque daba su 
sangre tuvo la osadía de sentirse un redentor, fue usted el que lanzó a unas humildes pulgas, que eran felices, a la misma miseria de la humanidad" (122).

Es más que evidente el mensaje que Jiménez nos plantea sin lugar a dudas: el resquebrajamiento que produjeron las dos guerras mundiales, la crisis del 29 y el período de entre guerras. Estos acontecimientos abrieron el camino para la incertidumbre humana. No hay espacio para la esperanza ni para la confianza en una redención.

Por lo tanto, el sabio viene a representar un genuino estado de conciencia sobre la verdadera naturaleza humana. Esto es, de la indiscutible posición pusilánime en la que se encuentra el género humano, a partir de la mala fe en la que se está viviendo. Entienda la mala fe como Sartre (1997) la definió, es decir, un engañarse a sí mismo. "Por cierto, para quien practica la mala fe, se trata de enmascarar una verdad. Desagradable o de presentar como verdad un error agradable. La mala fe tiene, pues, en apariencia, la estructura de la mentira. Solo que (y esto lo cambia todo) en la mala fe yo mismo me enmascaro la verdad" (93).

Este sabio (pulga-hombre) es la voz del escritor hecha metáfora. Camus (1980) decía que la obra de arte "es la única probabilidad de mantener la propia conciencia y de fijar en ella las aventuras" (104). Escribir, es vivir dos veces, afirmaba el literato francés. El mismo Jiménez (1999), de acuerdo con la afirmación anterior, alegaba que: "Los libros son consoladores, porque la obra de arte no es sino una rebelión contra la muerte, el artista busca manifestarse, confirmar su vida, dársela a otros objetos, seguramente por el temor de desaparecer completamente" (113). Lo que nos confirma una actitud sumamente crítica y pesimista. Tanto en su primera novela, Unos fantoches, así como también en su última novela, El jaúl, Jiménez (citado por Quesada) evidencia un fuerte pesimismo sobre la humanidad y así lo demuestra en una de sus candelillas: "Nada me es tan doloroso como la educación de mis hijos: es hacer esclavos para que vivan en un mundo de esclavos" (629).

En este sentido, el sabio viene a representar aquella parte pesimista que está convencida de “...que se aumenta más y más la miseria y las necesidades, dentro del adelanto, dentro del llamado progreso, dentro de mayor producción la gente se muere de hambre.(sic)" Estamos condenados y aun "confesándolo y reconociéndolo, no se puede volver atrás" (124). Es la consecuencia de vivir evadiéndonos y ocultando nuestra responsabilidad sobre nuestros actos.

No hemos hecho tabla rasa sobre lo dicho. No dudamos. Está la humanidad tan acostumbrada a lo dicho, que siempre está a la espera de un nuevo discurso que la oriente, algo que la guíe, algo o alguien que le brinde respuestas. Se prefiere hablar de lo ajeno. Divierte más comentar sobre los errores de otros y no sobre los nuestros. No contentos con esto, le exigimos a los demás ser iguales a nosotros, que sacrifiquen su individualidad y que se sometan a la cosificación de sus ser, de su voluntad, para así, vivir más cómodamente. "Tendencia es de las gentes el convertir a sus semejantes en muñecos de utilidad 
mecánica. La inquietud les molesta" (Max Jiménez citado por Quesada, 2004:67).

Algo similar expresa el filósofo costarricense Moisés Vincenzi (El hombre máquina, 1938) sobre esta tendencia de la civilización de prescindir de lo humano. “...hay que advertir que la civilización es algo frío que desconecta, cada vez más, el progreso obtenido de los intereses culturales de la humanidad. Y por eso nuestra época se caracteriza por haber roto la correlación armoniosa que debe existir entre lo civilizado lo culto, entre la carne y el espíritu" (11).

Por ende, la creciente mecanización de lo humano, así como la vida, fomenta la desaparición de lo particular y lo sustituye por lo autómata. Por lo demás, la pulga sabio simboliza aquella fe rota, aquel espejo agrietado, cuyo reflejo nos devuelve la imagen resquebrajada de nuestra condición humana trozos de nuestra voluntad.

El domador, aquel hombre que puso su fe en un ideal lleno de amor y luego es castigado con una muerte acompañada, en manos de uno de esos seres que pretendió emancipar, nos presenta la otra mejilla. Es el rostro de los que gritan: redención. Exoneración por nuestros errores, por aquello que hicimos, lo que no hicimos y lo que dejamos de hacer. Así se muestra en el texto de Jiménez:

El sabio tomaba un aspecto terrible, la barba se le convertía en una terribles ponzoñas, la cabeza se le disminuía, y se le aumentaba el tórax como un fuelle vacío, y ya lanzaba gritos agudísimos: - ¿No me reconoce usted? ¿No reconoce usted en mí a la pulga que se ha hecho hombre? Y de un salto, veinte veces más grande que su cuerpo, cayó sobre el domador. Y le chupaba la sangre, y se inflaba rojo el inmenso vientre del sabio, y en el borbotar, una voz agónica se apagaba:

- Un Redentor...un Redentor... (124)

\section{La autenticidad y la libertad}

En este apartado los temas existencialistas que tratan sobre la autenticidad como única forma de asimilar mi libertad como sujeto existente serán el eje central. Anteriormente, mencionamos cómo el sentimiento de angustia que experimenta el domador-libertador lo hace consciente de su libertad ante el fracaso de redención de las pulgas.

A partir de ahí hurgaremos en la existencia de algunas pulgas en particular. Dentro de esta obra encontramos un capítulo muy especial y que, a la vez, podríamos decir que se trata de un pequeño retrato biográfico que el mismo autor expone. Nos referimos al capítulo llamado La pulga artista:

La pulga nació con los ojos como quien ve el cielo en la tierra. Una pulga agobiada desde su niñez por un sentimiento de absoluta conciencia.

Una niñez miserable.

...Una pulga artista, dentro de lo que se llama entre las pulgas una familia honorable, siembra el desconcierto. 
Tener en el hogar una pulga que no gana dinero, y que hace deducciones, y hasta llega a medir que la vida es muy corta, y que miles de conveniencias sociales pulguientas son desastrosas y tontas, es una desgracia hogareña. Una pulga artista: un fracaso de todas las aspiraciones de amor y rectitud paternal (87).

El capítulo da comienzo con una clara intención del autor por retratarse en esta pulga artista. Se observa cómo el narrador se describe cuando afirma: "La pulga nació con los ojos como quien ve el cielo en la tierra. Una pulga agobiada desde su niñez por un sentimiento de absoluta conciencia" (87). Notamos inmediatamente cómo el narrador-escritor se inmiscuye dentro de la obra y se nos presenta como un individuo incomprendido por ser diferente. La pulga artista se niega a ser un engranaje más dentro de un sistema. Con las anteriores palabras Jiménez quiso afirmar su posición dentro de su familia, su cultura y su contexto social, desde su actitud artística, cuando el narrador omnisciente nos afirma que la pulga artista: “...dentro de lo que se llama entre las pulgas una familia honorable, siembra el desconcierto" (87).

Según uno de sus biógrafos, Alfonso Chase, cuando Jiménez decide abandonar la carrera de comercio para involucrarse en el estudio del arte, recibe de su padre rechazo y disconformidad, lo que produce en Jiménez serias crisis emocionales. Esto, como consecuencia, atrajo relaciones muy tensas entre él y su padre? "Los padres de la pulga artista no creían nada de la pulga

7 A propósito, véase el cuadro cronológico del libro sobre Max Jiménez de Alfonso Chase. hijo, al cual le gustaba la soledad, y levantar la cabeza cuando había estrellas, y preguntar mucho, sin preguntar nada" (87).

En las palabras anteriores, la voz narrativa nos describe a una pulga absorta en la reflexión. Una pulga aliada de la soledad y que nos recuerda, también, a aquellos primeros filósofos griegos que suspendidos en la admiración de la recóndita naturaleza alzaban la cabeza para contemplar el cielo estrellado y lanzar preguntas confusas, que en la mayoría de las ocasiones servían para multiplicar las preguntas y con muy pocas respuestas.

Además, está disconforme con el medio social y cultural, dado que reflexiona y reconoce que "miles de conveniencias sociales pulguientas son desastrosas $\mathrm{y}$ tontas,..." (87). En este sentido, la pulga artista proyecta su propia sensibilidad frente a los convencionalismos sociales. Sobre estos dos capítulos nos interesan dos cosas: una tiene que ver con la autenticidad y la otra con la libertad frente a un mundo tiránico.

En primer lugar, vamos a entender por autenticidad cuando un ser humano es o llega a ser. Cuando este no se encuentra enajenado $^{8}$. Es auténtico cuando aquel sujeto se concibe sin dudas, sin vacilaciones. Por otra parte, podríamos hablar del "yo auténtico" entendiendo que, el "yo auténtico" no puede dejar de ser lo que es. "La pulga artista siguió su destino, el destino de una pulga

8 Aunque como señala Ferrater Mora (1975) en su diccionario de Filosofia: "en ocasiones puede considerarse que la enajenación es uno de los rasgos esenciales de la existencia humana, de modo que en tal caso el estar enajenado, y aun de modo más radical el no ser sí mismo, es uno de los caracteres del auténtico ser" (159). 
artista es algo terrible, es algo así como la conciencia de lo eterno, conciencia del pasado, y futuro en presente" (88).

La pulga es auténtica porque no se vende, se ve y se proyecta como la pulga artista que es. Esta ha tenido que enfrentar las diferencias con su familia para conservarse intacta; ve el cielo en la tierra, porque prefiere mirar lo sobrehumano por sobre lo humano, lo esencial frente a lo ordinario. Así se refiere en el texto:

el alma de una pulga artista es como la inquietud de una mano ciega: los objetos, descubiertos por la vista de la mano, son como la realización de la obra de arte, que van confirmando la existencia (89).

Antes bien, la pulga artista posee la conciencia y la libertad. Carece de valores preestablecidos; ella no se disfraza y en un mundo de apariencias se nos revela tal cual es. La pulga artista convive a diario con la indiferencia de las otras pulgas (tal cual padeció Jiménez en su tiempo). Esta no es comprendida en de su expresión artística, su sensibilidad ante un mundo de progreso industrial y donde el arte debe adquirir o al menos poseer algún fin pragmático.

Asimismo, Jiménez planteaba el desdén con que el artista mira a la sociedad burguesa, así como la masificación de los individuos. Ya en una de sus candelillas afirmaba que "el artista es el más desgraciado de los hombres si tiene que cumplir con deberes sociales." (Citado por Quesada, 2004: 632) Así, la pulga artista, nos dice el narrador omnisciente, se conserva incólume, auténtica diríamos, pues a pesar de los mecanismos de cosificación que el progreso exige, ella y su arte se mantienen íntegros, ya que "el arte puro es fuego para los falsos valores." (Citado por Quesada, 2004:645). Así se evidencia en el texto de Jiménez:

La pulga artista no vendió, no entregó el talento ni el sentido artístico a ningún móvil político, el arte 10 conservó esencial. Hay pulgas medio artistas que luchan entre el arte y la miseria del mundo, y terminan por querer abarcarlo todo y por convertirlo en mezquino servicio. No resisten la absoluta independencia y libertad relativa de la pulga verdaderamente artista $(89,90)$.

\subsection{Los otros y mi autenticidad}

En cuanto a la autenticidad, el existencialismo sartreano nos dice que: "En consecuencia, cuando en el campo de la autenticidad completa se reconoce que el ser humano es un ser en quien la existencia precede a la esencia, que es un ser libre y que no puede, en diversas circunstancias, sino querer su libertad..." (Sartre, 1997: 69). Esto quiere decir que un ser libre no puede no ansiar su libertad y, por tanto, desea la libertad de los otros. También, descubrimos que nuestra libertad, al comprometernos con esta, nos obliga a reconocer la de los otros. Esto, como parte de un humanismo existencialista que reconoce que "el hombre no está encerrado en sí mismo sino presente siempre en un universo humano". La libertad, por ende, es elegir, a cada instante, de qué manera voy a mirar a las demás personas y el mundo. Según el existencialismo, el ser humano está en el mundo, así que está a la vez 
junto con los demás. Y se establece con los otros una relación de coexistencia.

En la obra El domador de pulgas, el capítulo llamado El filósofo sexual y la pulga puta, nos ofrece en esta ocasión, la situación de una pulga prostituta libre de prejuicios y la de un filósofo con "afición a la filosofía prostibularia” (Jiménez: 56). Ambos singulares personajes pulguientos conviven día a día con los "otros", aquellos que por ausencia de reflexión, de conciencia sobre su libertad, son instrumentos mecánicos favoritos de un "orden social" que constriñe a los sujetos existentes a continuar estereotipos sociales, modelos de conducta que los van llevando a un matadero cuyo máximo objetivo es el asesinato de nuestra humanidad.

Antes bien, se debe tener presente que durante toda la novela la metáfora de la que se sirve Jiménez (las pulgas-hombres) permite el enfoque crítico para tratar temas tabúes de la época, como por ejemplo: la prostitución, la brujería, el sexo, el alcoholismo, entre otros. Además, trata temas que, como parte del imaginario ideológico costarricense, son mostrados con cierto carácter desmitificador y satírico. Ahora bien, el filósofo sexual, una pulga que como afirma la voz narradora "andaba con los ojos abiertos sin ver nada,...” (Jiménez: 55) comenzó a desarrollar un interés por los temas sexuales, los temas de prostíbulos.

$\mathrm{Su}$ afición a la filosofía prostibularia, le vino cuando una meretriz le probó que ella era pura de alma, que ya estaba libre de prejuicios, y que en cambio otras con el cuerpo de rodillas estaban bien necesitadas de desinfectantes del alma. Al oir (sic) aquellas palabras, ese día, el filósofo pulga sintió muy en mengua los apetitos de la sensualidad (56).

Observemos dos cosas con respecto al ejemplo anterior. Una, que la pulga puta le mostró al filósofo sexual que ella estaba libre de prejuicios. Ya en este ejemplo de palabras, el narrador nos plantea, como en ocasiones, aquello que la sociedad cancela en nombre de una moral ideológica, implementada con el único fin de ocultar o enmascarar una realidad latente y silenciar (en este caso a las pulgas putas) lo que en nuestra realidad social y cultural es considerado como desechos sociales. Es más fácil juzgar a estas "humildísimas servidoras del amor", (56) que intentar "irse a los planos no expuestos bajo lo corriente" (55). Por ende, es una crítica a la mojigatería, a la doble moral, visto que "otras con el cuerpo de rodillas estaban bien necesitadas de desinfectantes del alma" (56).

"El infierno son los otros" decía Sartre y cuán ciertas son estas palabras. Los otros imprimen de significaciones a las cosas y a los sujetos. Los otros, mis prójimos, estampan en discursos nacionalistas patriarcales una suerte de mitificación como parte de la construcción de la identidad de un país. En Costa Rica se logra a partir de la conformación de la mitología nacional, héroes, símbolos, canciones, literatura pintura, arquitectura y otros.

Se opera ocultar el "lado oscuro" de nuestra cultura. Jiménez lo supo muy bien quizá, por eso se negó a escribir sobre campesinos labriegos y sencillos, mujeres fieles y sumisas en sus hogares. En fin, se 
negó a ser parte de aquellos que encubrían la compleja realidad costarricense. Prefirió mostrar la farsa, el lado umbrío de nuestra sociedad puritana:

La dignidad del prostíbulo está en contar quién fue el burlador estúpido, que las lanzó a la carrera, generalmente una pulga de automóvil y nombre heredados. Nunca el menor rencor contra aquel hombre que las llevó en su engaño a la renunciación de las apariencias sexuales, de ese mundo pulguiento el cual ellas bien sabían que era una farsa, y ellas, con dolor de la ironía, contaban que el mundo externo lo llamaban puro (57).

El otro aspecto por señalar es el que gira en torno a las renunciaciones como una forma por alcanzar nuestro estado de autenticidad. La pulga puta al igual que la pulga artista se ven en la necesidad de renunciaciones. La pulga artista se debe a las renunciaciones para fortalecer su voluntad y su ser frente a una sociedad que no acepta su particularidad.

La pulga artista tuvo varias renunciaciones, la vida se forma de quitarse partes, para que puedan sobrevivir las otras. Renunciar es desprenderse, y de ahí salen, como en las podas, las nuevas brotes con más fuerza (89).

Precisamente, renunciar es desprenderse, advierte la voz narrativa. Pero, ¿cuáles serían aquellas renunciaciones a las que se somete la pulga artista? Quizá, volverse un empedernido discerniente de la sociedad $\mathrm{y}$, con esto, aceptar ser considerado enemigo. Decía Jiménez que "no se puede ser artista y ser sociable" (Citado por Quesada, 2004:612).

Pero, ¿qué sucede en el caso de la pulga puta?, ¿cuáles habrán sido sus renunciaciones? A diferencia de la pulga artista, de la cual tenemos que deducir e interpretar pues carecemos de más información, sabemos que la pulga puta renunció a las apariencias sexuales. Esto significa, según Jiménez, el desprendimiento "de todas las conveniencias sociales: la libertad de la pulga llamada mala, porque renuncia a un cuerpo,..." (57). Asimismo, esta renunciación la llevó, a la pulga puta, reconocerse a sí misma y sobre todo a distinguir que aquel mundo pulguiento con moral intachable "era una farsa" (57).

Ahora bien, el personaje, el filósofo sexual, se adhiere a la filosofía prostibularia, porque "decía que en tales lugares la observación de la vida y las deducciones eran de extremado interés" (55).

En definitiva, aquel filósofo de los temas sexuales constató cómo en aquellos lugares donde se respira el sugerente humo del deseo, las personas se muestran tal cual son. No hay máscaras, no hay conveniencias sociales que turben. Y es interesante evidenciar cómo el filósofo sexual, al mismo tiempo que observa cómo aquellas pulgas entregadas a los placeres sexuales están libres de las conveniencias sociales y se muestran tan auténticas, tan ellas, frente a una sociedad que no soporta ni verlas ni hablar de ellas, porque estas representan el "revés del cuadro" aquella

9 Se sigue con esta expresión a Álvaro Quesada Soto en su ensayo Metáforas de la enajenación 
realidad subyacente, pero que aceptarla significa tener que admitir que no somos perfectos. Y piensa el filósofo sexual, simultáneamente, en lo cruel que puede ser la sociedad con errados pretextos sociales con aquellas humildes trabajadoras. La pulga filósofo reflexiona sobre esa doble moral, sobre caballeros "municipales" de "reloj de traba" demandando los servicios de aquellas servidoras de amor para, después, marcarlas "con el sello de indeleble de la prostitución" (61). Esto también lo muestra Jiménez en la siguiente cita:

Y midió el filósofo, con la vara de la imaginación, en dónde estaba la filosofía y en dónde la bondad y sintió por las pulguitas de alma tan buena, tan vejadas. Metiéndose por ganar el sustento con pulgones asquerosos y municipales, ventrudos, de cadena gruesa y reloj de traba. Con la terrible limitación del amor porque se es puta, y con la terrible maldición de las gentes buenas, de estar criando una hija en el mismo molde vital de la madre (60).

Con respecto a los convencionalismos sociales, jamás dejaría Jiménez pasar la oportunidad de poder criticar a una de las instituciones más preciadas para aquella sociedad costarricense en formación. Hablamos pues, de la institución que representaba ${ }^{10}$ la familia, amparada, por supuesto, en el "sagrado" sacramento del matrimonio.

El filósofo atribuía muchos de los vicios en la misma rama, al miedo infundido por los padres en las

10 Y todavía es hoy una de las instituciones más protegidas por el Estado. pulguitas jóvenes a los pulgas machos, por lo menos hasta que no llagara al santo matrimonio. El matrimonio era una legalización eclesiástica, de los actos sensuales en las pulgas, de ahí resultaba una unión, que al tener hijos, se llamaba la familia, la cual en miles de ocasiones era una cosa desastrosa, pero que se sostenía entre las pulgas por algo que llamaban el nombre de los hijos, en tanto pulgas hogareñas, hogares también llamaban esa unión, se tiraban los platos (58).

Notamos que Jiménez no solo hace una explícita crítica a la gran mentira que en la mayoría de la ocasiones representa la familia, sino también a aquella "legalización eclesiástica" de los actos sexuales, es decir, el matrimonio.

No por algo, afirma Alfonso Chase en su artículo, Nuestro Max Jiménez (1994) que: "pocos escritores nacionales, en su proyección universal, lograron definir el alma auténtica de nuestro pueblo como Max Jiménez..." (s.p.).

Esta es la concepción patriarcal de la familia que el discurso nacional oligárquico operaba por aquellos años (nos referimos a los primeros 40 años de la centuria anterior) y que, como parte de la creación de la nueva República Nacional, ratificaba con efectividad y vigor.

Álvaro Quesada Soto (2010), en su libro Breve historia de la literatura costarricense, nos especifica con más brío la situación en la que se encontraba la concepción de familia por aquellos años en 
que el discurso oligárquico mostraba su apogeo. Asimismo, predominaba el carácter de doble discurso que se pretendía con el ideal de familia, en tanto fortaleciera al orden patriarcal y avivara el respeto a la autoridad.

Se establece de esa manera una homología entre familia oligárquica y nación, que asimila el dominio ejercido por el padre sobre su mujer, sus hijos y su patrimonio, con el dominio político-social ejercido por el patriarcado oligárquico sobre sus mujeres, su pueblo y su nación. El dominio y las relaciones de poder se asocian así a las nociones de propiedad, orden natural, amor y armonía familiares, amenazadas por la anarquía o el libertinaje asociados a la introducción de costumbres exóticas, deletéreas y subversivas.

Ese esquema privilegia una formación social elitista, jerárquica y represiva, que controla desde la vida sexual y las uniones matrimoniales y familiares, hasta las relaciones sociales, económicas y políticas (26).

Seguramente, por estas razones y de forma bastante explícita. Jiménez desacredita el ideal que se tenía y se pretendía infundir por aquellas fechas en relación con el concepto de familia, presentándolo meramente como una gran farsa del discurso oligárquico.

En este sentido, y asumiendo la valiosa información proporcionada por Quesada, se coteja la carga ideológica de la que era partícipe la institución de la familia. Sobre todo en el acto de equipararla con la
Nación, lo que significaba forzarla aún más a entrar en el molde de lo que podríamos llamar la Costa Rica perfecta y feliz.

Así, Jiménez participa, con la ayuda del filósofo sexual, de una sátira que reclama no evadirnos bajo la túnica de los pretextos ideológicos y asumir lo que realmente somos como pueblo, como cultura, así como evitar idealizarnos al extremo de aparentar lo que en realidad no somos para buscarnos en la crítica, reconociendo nuestros errores y aciertos.

Claro está la pulga, tan metida en asuntos de la carne, la pulga filósofo sensual, llegó a desacreditarse, pero era visto como las cosas que se codician por prohibidas. Y hasta recibía consultas, porque como consta, dentro de las pulgas se había complicado muchísimo la sensualidad pulguienta. Una pulga de pensamiento libre le escribió al filósofo que eso de llevar el honor de la cintura para abajo le aburría muchísimo; el filósofo que era llano le contestó que se desaburriera. Pero la pulga, de pensamiento libre, pero tradición más fuerte, siguió con su molestia (59).

En una sociedad tan conservadora como la Costa Rica de aquellos años, no sería difícil imaginar lo que este libro pudo haber provocado en la clase burguesa. De lo engorroso que pudo significar para aquellos intelectuales ${ }^{11}$ de la época acoger con humor aquel retrato efusivo que buscaba

11 Nos referimos a aquellos intelectuales que formaban parte de la oligarquía cafetalera, que aunque no necesariamente intelectuales, por lo menos eran parte de la clase hegemónica del país. 
parodiar y criticar los convencionalismos en los que estaba basada nuestra identidad. "La pulga filósofo no parecía encontrar mucho auditorio pues sus metáforas morales ya iban demasiado lejos, ver lo oculto con simpleza, necesita pulgas de continua contrariedad y rebelión" (56).

Pues bien, se necesita más que pretender tener un "pensamiento libre". Se debe, también, despojar de toda máscara que dificulte la visibilidad; se debe tener, a la vez, la suficiente valentía para reconocer la farsa. Que no somos los "labriegos sencillos"12 que menciona nuestro Himno Nacional. Que estamos muy lejos de ser la Suiza centroamericana. Que adjetivos como trabajadores y pacíficos no son nuestros mejores atributos.

No obstante, el fervor del discurso sobre "nuestra identidad nacional", hizo que ticos y ticas prefirieran creer que la verdadera cultura residía en el Valle Central y que en verdad éramos parte de una blanquitud heredada de Europa y en la armonía de las relaciones de nuestro pueblo, en la fe incuestionable en los cánones religiosos y los juicios morales de los representantes del poder eclesiástico. En fin, Jiménez sabía de antemano que éramos pillaje de valores ajenos, valores acordes con la cultura de Europa (cultura que por cierto se encontraba desintegrada a raíz de las crisis

12 Ya en su tercera y última novela El Jaúl, Jiménez nos señala que: "La tranquilidad del pueblo es la más completa de las farsas. El templo y las casitas bajo la lluvia, los árboles que albergan el canto triste de los pájaros, las auroras, las noches de estrellas, el romance campesino, el arado, la yunta, el río que se crece, el perro faldero, el mugir de las vacas, la gleba, son simples testigos de que la intriga es la más constante y la más sutil de las dedicaciones del pueblo, que solamente desea ver hundirse al vecino." $(1997$ 32, 33). bélicas) y, que ignorábamos nuestra realidad latinoamericana. Y aseveraba también en unas de sus candelillas que: "Es absurdo buscar en los otros lo que ni siquiera podemos encontrar en nosotros mismos" (Citado por Quesada, 2004:617). Nuestra realidad era demasiado amarga para ser percibida por miopes enamorados de la sofisticación europea, ignorando, así, nuestras voces más auténticas.

Con motivo de lo anterior, Jiménez hizo de su arte plástico, lírico y narrativo, un recordatorio de lo desatinados que estábamos con nuestras raíces. Por eso, Jiménez nos presenta la autonomía con la que la pulga puta y el filósofo sexual se mueven frente a un mundo lleno de dobles morales, que es juez y verdugo a la vez. Una pulga puta libre de los prejuicios sociales y un filósofo sexual que se encuentra confundido con respecto a la moral y la ética, no tienen una verdadera guía moral, porque la misma sociedad contradictoria condena, esconde y reprime, luego busca lo prohibido para conocerlo y experimentarlo e inmediatamente volver a condenar, esconder y reprimir. Es una sociedad donde constantemente se libra la batalla del ser y el parecer, de lo auténtico frente a lo inexacto. Es la oposición entre lo que somos y lo que los otros pretenden que seamos; entre lo que creemos y lo que los demás quieren que creamos.

Jiménez mencionaba en su artículo Libertarse, que los otros desean vernos convertidos en "muñecos" de "utilidad mecánica" (citado por Quesada, 2004:67), porque "la inquietud les molesta". La pulga puta y el filósofo sexual son personajes, así como la pulga artista y la pulga lírica, 
que inquietan, desintegran, invierten, deforman y provocan el caos. Son personajes "que se apartan de la monotonía" (67) y eso en una sociedad como la nuestra es un malestar, una comezón que no termina de importunar. Habrá que seguir el consejo de Jiménez: aumentar la lucha y el trabajo "contra el orden mecánico".

\section{Libertarse}

Libertarse es un ensayo de Jiménez donde insiste en esa tendencia que tienen los otros de convertirnos en muñecos mecánicos, ausentes de voluntades propias y absortos en la mala fe. Decía Jiménez (Candelillas, citado por Quesada, 2004:600) que: “escribiríamos mejor si no tuviéramos el miedo de que descubran lo que somos." Y con esto parece declarar la dificultad con la que batallamos día a día para mostrarnos como somos. Asimismo, de cómo el temor hace presa fácil de nuestros más sinceros pensamientos y sentimientos.

No obstante, Jiménez a través de su novela El domador de pulgas nos muestra que en el arte de escribir se puede hacer crítica con la sátira, la ironía, mofándose de toda la regla literaria y retando a la sintaxis. Claro está que Jiménez coqueteó con el vanguardismo, permitiéndose con este galanteo experimentar con alas propias las cumbres de lo nuevo. Así, él hizo del arte el medio y el mejor de los instrumentos para comunicarse.

Francisco Amighetti (en la introducción al libro El domador de pulgas, 1999) decía que Jiménez escribía como hablaba, "sus libros los hizo con todo su cuerpo y toda su sangre" (8). Por esto, su segunda novela, El Domador de Pulgas, es una contestación a una visión de época. Vapuleó el orden social costarricense al tratar sobre la enajenación que los discursos dominantes opresivos, así como el estado de incertidumbre y falsedad, imponen en los individuos. De ahí su carácter universal, propio de un Jiménez que fue extremadamente viajero. Esto le habilitó para conocer más de cerca las costumbres humanas y evidenciar, de paso, los restos de aquella utopía racionalista.

A continuación veremos cómo mediante la metáfora, pulgas-hombres, Jiménez se sirve para presentarnos un enfoque satírico de la sociedad costarricense y el mundo en general. Una sátira que, como manifiesta Quesada (2004): “ofrece variaciones paródicas acerca de las relaciones entre naturaleza, cultura y civilización o entre libertad, identidad y enajenación" (39).

Por lo tanto, siendo esta novela una metáfora acerca de los pilares sobre los que descansa la civilización occidental, así como de nuestra sociedad costarricense, tomaremos en cuenta los capítulos La colonia agrícola, La pulga que abortó y El rey pulga, donde el escritor da fe de bufonearse de los estereotipos sociales, no solo, los que afectaban a los y las costarricenses de principios del siglo anterior, sino también a la humanidad de aquel entonces.

Hemos mencionado en repetidas ocasiones la importancia de la autenticidad, de ser genuinos y así asumir luego nuestra libertad, pero en un mundo de farsas, incluso la libertad puede ser mentira. Y nadie puede ser libre o pretender afirmarse libre si funciona como títere de una farsa. 
No hay institución que se mantenga en pie en la novela El domador de pulgas. Jiménez arremete contra todas, pues, estas son engendradoras de estereotipos sociales que contribuyen a crear aires nebulosos que dificultan mirar claramente. Por lo cual, no es de extrañar que la Costa Rica de los primeros cuarenta años de la centuria anterior, mirara con desprecio el trabajo artístico y el mensaje de Jiménez. Así lo confirma Araujo (1999):

Y, ¿cómo no? Si además Jiménez mediante polémicos artículos y textos literarios, les decía a sus compatriotas las cuatro verdades que normalmente a los costarricenses todavía hoy no nos gusta oír: hablaba de la hipocresía de la sociedad, de la falsedad de muchas de nuestras costumbres y de la mentira de nuestras imágenes de identidad: el cuento de que somos una isla en América, y que somos mejores que el resto de Centro América: más blancos, más cultos, en fin... (55).

Ya esa actitud crítica y rebelde hacia el pensamiento del país, y contra todo orden social, se percibe en varios de los capítulos de El domador de pulgas, cuyo fin era mostrar su actitud contestataria hacia el falso ideario costarricense.

Nos enfocaremos en concurrir algunos de esos cuadros en que Jiménez advierte de nuestra ilegitimidad como pueblo.

Los capítulos La colonia agrícola y la pulga que abortó, además de ser claras parodias de la supuesta "apacibilidad" del pueblo, son preámbulos de la última novela de Jiménez, hablamos de El Jaúl.

En estos dos capítulos de la novela El domador de pulgas, se advierte una clara intención de ridiculizar al extremo todo aquello sobre lo que estaba fundamentado nuestro ideal. Por ejemplo, en La pulga que abortó, Jiménez planteaba una crítica al precepto del catolicismo sobre el papel de la mujer en el proyecto de la familia, que entiende la unión de pareja como fin para la multiplicación de la especie. "Las creencias complicaron la maternidad, debían multiplicarse las familias, así las pulgas hijos tuvieran que morirse de hambre" (35). Esto es una clara crítica al concepto que guarda el catolicismo sobre el valor de la maternidad.

Jiménez aprovechó, también, la oportunidad de destemplar la imagen de la mujer sumisa y fiel sobre la que durante el siglo $\mathrm{XX}$ se venía insistiendo entre las y los costarricenses como parte de la identidad nacional. Es así como en La colonia agrícola y en La pulga que asesinó, nos narra las siguientes historias pulguientas sobre pulgas-mujeres "dóciles":

Pero, el problema moral se complicó mucho, el amor trastornó el campo: a una pulga hijo llegaron a decirle que su mamá se había ido con un pulgón sano y fuerte de la colonia, el mismo pulgón que usaba un pañuelo de seda al cuello, lo cual era bastante para que nadie se le resistiera. El hijo pensó: mi mamá no puede ser puta (era gente de pensamiento simple) y se trajo a la mamá... (30) 
El zapatero mató a don Juan, desde luego, por la pulga Pascuala. El nunca lo habría matado, menos aún con el martillo de remendar zapatos, sino hubiese sido porque Pascuala le confesó todo su pecado. Ya en las pulgas se estilizaba la sinceridad y pertenecían a un club que se llamaba La Mujer Sincera. Es verdad que muchas de las pulgas tenían amantes, pero era porque algunas de las socias practicaban lo que se llamaba la sinceridad interior, que era ser honradas con los propios deseos $(45,46)$.

No hay ornamentos. Jiménez no embellece ninguna realidad. Disfrutó desgajando la piel del ideario costarricense y de esta proeza descubrió facciones que hieren, que sus coterráneos no querían mirar ni oír. Incomodó incluso con el lenguaje utilizado en la novela palabras como "culo", "imbécil", "aborto", "mierda" y "puta", significaron para el lector "culto" de aque1la época una verdadera profanación a las normas de ética y decoro social.

Por otra parte, desde esta óptica crítica, Jiménez se permite tratar toda clase de asuntos concernientes a la moral cristiana, política y cultural creando así una atmósfera de lo irreverente.

Jiménez, de la mano con la ironía, dedica un jocoso episodio a mostrarnos cómo un rebaño insensato es incapaz de pensar por sí mismo; además, evidencia una crítica satírica hacia los regímenes totalitarios en el mundo; resultado de la mentalidad de rebaño que posee la humanidad.
La masa de pulgas tonta se crearía tiranos y se rebajaría a la absoluta nulidad, a la igualdad, para darle el poder a un solo hombre, tirano que probablemente se llamaría "el amigo del pueblo".

Cuatro pulgones y pulguillas decretarían las guerras, y las pulgas chivos irían en rebaños a asesinarse contra otros infelices, cuyo único pecado era hablar un idioma diferente. ¡Ah!, pero los pulgones impulsadores de la guerra pasarían a la historia, parte de las masas, tal vez las que se creían letradas, se aprenderían sus vidas y creerían que aquellas pulgas estaban dotadas de poder divino (25).

Al mismo tiempo, Jiménez aprovechó para asomar su visión sobre la guerra, como aquel caos que con su mano incontenible aniquila inocencias, silencia las voces y reprime libertades.

Cuando hacía falta suprimir una pulguita rebelde de esas que no quieren a los tiranos, y que dicen que el progreso es una farsa conseguido en ese caos; a fuerza de sangre de pulguitas inocentes, el líder se encargaba de que alguno de sus propios hombres amaneciera muerto; entonces se culpaba a la pulga rebelde del crimen, y se le mandaba fusilar."(94)[...]"La pulga líder siempre tenía tiempo de hacer mucho daño, porque mandaba matar pulgas salvajes, de esos que comen frutas silvestres, y que les hacen heridas a los niños en la cara para retirar los malos espíritus, y que 
mataban tres hombres para tener una mujer. Un sistema bastante original de tener una mujer (96).

Por otra parte, y bajo este mismo planteo, es importante la crítica que Jiménez empuña a la democracia. Jiménez aseguró en Diario de Costa Rica en el año 1934 que: "La elección de nuestros presidentes se efectúa entre el capital, el gobierno de los políticos y la víctima que es el pueblo" (Max Jiménez, citado por Chase, 1973: 52).

Así pues, en el capítulo El rey pulga, Jiménez se mofa, siempre bajo el velo de la ironía y la metáfora, de los distinguidos gobernantes de nuestra Patria, como también del pueblo ovejuno que los elige y se conforma.

El rey pulga

¿Qué hay de nuevo? Me imagino que lo mismo que solamente quieren o que aparentan quererme los que reciben dinero del reinado. (Hace señas a un sirviente para que le sirva whisky, el cual le trae desde luego. El rey agrega:) Mas, más...

Un cortesano Pulga

Majestad voy a seros franco, el pueblo cada vez os quiere menos. Además dicen que vivís borracho.

Los otros dos cortesanos pulgas

¡Dios mío!

El rey pulga

Usted es el hombre honrado (palmada en el hombro), en cuanto a lo de beber alcohol, no sé por qué me lo critican, yo soy solamente una parte de mi pueblo.

Dad órdenes para que se diga al pueblo que voy a poner otro rey, buscaremos uno del pueblo de ellos mismos, un mendigo, una persona humildísima. Veremos lo que dicen.

\section{ACTO SEGUNDO}

(Han vestido a un campesino de rey, el rey pulga verdadero está con él al lado del trono. Entra un cortesano)

El rey pulga verdadero

¿Qué dice el pueblo encantador de su nuevo gobernante? (Desde luego está borracho el rey)

\section{La pulga cortesana}

Están aterrados, dicen que esa pulga no es noble, que sólo lo noble puede dar buenos gobernantes, y que no hay peor pulga que la del mismo palo. Y además ese rey nuevo puritano no se emborracha.

\section{El Rey}

(Se ríe mucho, con risa de tirano terrible).

¡Ah!, pues a quien no quieren es al rey, no es a mi, seguiré gobernando, llévense a ese cochino.

(Telón y probablemente muchos aplausos) $(101,102,103)$. 
En este capítulo, Jiménez trata el proceso democrático de nuestro país como un proceso políticamente conservador a favor de la clase privilegiada de la Nación. A mediados del siglo XX (1900-1930), el ochenta por ciento de la población costarricense era analfabeta. Lo que nos dejaba solo un veinte por cierto de coterráneos con índices altos en educación y conocimientos en política.

Esto, y según el manual de Instrucción Cívica del año 1898, propuesto por el tres veces presidente de Costa Rica, don Ricardo Jiménez Oreamuno, donde según Juan Rafael Quesada Camacho (referido por Quesada Soto, 1998), en el manifiesto de nuestro expresidente, se hace énfasis en el sufragio universal, permitiendo así a cualquier ciudadano el libre derecho al voto.

Pero antes, nos señala Quesada Soto en Los Unos y los Otros (1998), que en aquel tiempo no todos los costarricenses tenían para el ilustre patricio el rango de ciudadanos capaces de ejercer sin limitaciones sus derechos (25).

Ya que, como afirma el historiador, Juan Rafael Quesada, para don Ricardo Jiménez Oreamuno: "el vulgo, la mayoría de la población, no tiene luces suficientes para discernir cuáles, entre los hombres públicos, son los que mejores garantías dan [...] de manejar bien los intereses del país” (Juan Rafael Quesada Camacho, citado por Quesada Soto, 1998, 25).

Por lo tanto, cuando la pulga rey da la orden al cortesano "para que se diga al pueblo que voy a poner otro rey, buscaremos uno del pueblo de ellos mismos, un mendigo, una persona humildísima...", y luego cuando la pulga cortesana le anuncia al rey pulga que las personas del pueblo "están aterrados" y "dicen que esa pulga no es noble, que sólo lo noble puede dar buenos gobernantes, y que no hay peor pulga que la del mismo palo", al igual que la voz narrativa, Jiménez no hace otra cosa más que subrayarle a sus coterráneos que ellos mismos forman parte de un circo político, donde los padres de la Patria simplemente los utilizan como medios para legitimar su poder. Nos sugiere Quesada (1998) en su libro Uno y los otros que:

En manos de la oligarquía cafetalera se concentra la riqueza, el control político y administrativo del aparato estatal, y las tareas de dirección, organización y distribución del trabajo y sus frutos. Este esfuerzo se legitima mediante un proceso paralelo de unificación ideológica alrededor de un proyecto civilizador, a partir del cual se elabora un concepto de nación que permite identificar el orden oligárquico con la realidad nacional, y las representaciones oligárquicas con el patriotismo (26).

El fragmento anterior habla claramente de la posición en la que se encontraba el pueblo costarricense. Posición de la cual, todavía hoy, Costa Rica no ha sabido escapar. Nuestra educación no contribuye a la creación de verdaderos líderes, sujetos integrales. Día a día nuestra educación concurre a robustecer el "temperamento ovejuno" en las y los costarricenses. Los releva de la tarea del pensar. Entran desde muy jóvenes como manada al degolladero que significan los centros educativos, los cuales imponen un tipo de educación, que 
a grandes rasgos, solo beneficia los intereses políticos. Y, según Jiménez (citado por Quesada, 2004) en una de sus candelillas: "nada es tan trágico como una persona que educando impone su educación propia. Lo que se consigue son niños que nacen castrados" (669). Si una parte de nuestros coterráneos no está, como tampoco lo estaba en aquellos primeros años del siglo anterior, en la capacidad de discernir entre un hombre integral y honesto, de uno que solo busca beneficiarse de la política, es, a causa de la falta de herramientas educativas que promuevan la criticidad en nuestros y nuestras estudiantes.

Max Jiménez (citado por Quesada, 2004) afirmó por aquellos años, en una de sus candelillas, que es: "mejor la tiranía que una falsa libertad" (644). No se equivocaba el escritor costarricense, todavía hoy se habla de democracia como aquella que se instaura cada cuatro años. La democracia en este pequeño país versa sobre dos viejos contrincantes, esto es, dos partidos políticos que compiten entre ellos como una escasa minoría que se reparte el poder.

La libertad, así como las oportunidades, son ambas simples palabras que nuestros representantes utilizan con mucho entusiasmo en la propaganda política, pero están muy lejos de la praxis social. Muestra de esto es el caso de la comunidad homosexual. Nuestro país es presa de un discurso religioso tergiversado ${ }^{13}$ por

13 Un caso es la reciente entrevista que la periodista Pilar Cisneros de Telenoticias le realizó al diputado don Justo Orozco, Presidente de la Comisión de los Derechos Humanos, el día 7 de junio de 2012, donde Orozco afirmó, bajo sus creencias religiosas: "que las preferencias homosexuales van en contra de la naturaleza, de la creación. ¿Acaso ellos pueden reproducirse?" detener los derechos esenciales dentro de las uniones civiles de personas del mismo género. Mismo discurso que también se utiliza para detener la fecundación in vitro, la eutanasia y el aborto. Con respecto a las oportunidades, está de más decir que no todo niño y niña y adolescentes tienen la oportunidad de acceder a una verdadera y excelente educación. Si hablamos de salud, topan con mejor suerte aquellas personas que acuden a la medicina privada o cuentan con los medios para comprar lo último en medicinas. Con democracias así: "mejor la tiranía que una falsa libertad."

Para Jiménez, la democracia, es gregarismo puro. No incita a perseguir ideas propias. En cambio, el pueblo dócilmente persigue las opiniones ajenas. Esto último no es gratuito. El mismo Jiménez viviendo "bajo el amparo de una democracia", vio cómo su obra artística era censurada, porque quizá algunos la consideraban soez. El escritor costarricense Alfonso Chase (1973:110) comparte y da fe de lo anterior cuando menciona lo sucedido con la primera novela de Jiménez, Unos Fantoches, que ocasionó un fuerte escándalo dentro de la burguesía costarricense y llevó al autor a retirar la obra de las estanterías del país.

Además, Yolanda Oreamuno (1964) en su ensayo Max Jiménez y los que están, mencionó que en una ocasión los estudiantes de ingeniería de la Universidad de Costa Rica, intentaron destruir las estatuas que Jiménez confirió a ese centro de cultura.

De sus esculturas y su contacto con el público costarricense queda el desagradable incidente que protagonizó su Maternidad al ser exhibida 
en la Universidad de Costa Rica y el agravio que sufrió de los mismos estudiantes, al burlarse estos y colocarle objetos inapropiados para manifestar su incapacidad, o tal vez su impotencia en reconocer el esfuerzo creador de Max Jiménez (50).

Finalmente, el texto deja la incertidumbre de un mundo que a falta de conocimiento no tiene claro cuál es su papel y deber como sujetos existentes, producto de discursos enajenantes que excluían la multiplicidad de sujetos y voces cohibidas (negros, indígenas, mujeres, jóvenes y niños) que habitaban, y habitan, la Nación. La identidad particular se somete ideológicamente a una identidad homogénea.

Si alguien es diferente por distintas razones, ya sea por su orientación sexual, por el color de su piel, por su credo, entre otras justificaciones, es acusado, o acusada, de romper con el orden establecido. Se trata de minimizar a aquella persona que es distinta, de modo que, tarde o temprano, aquella renuncia a su particularidad y, poco a poco, se va sometiendo al discurso de la homogeneidad.

Esta tendencia que insiste en una unidad, en callar la existencia del "otro", hasta lograr que se convierta en "nosotros", es herencia de aquel discurso nacional oligárquico enajenante. Esta unidad imaginaria no pretende otra cosa que reprimir la existencia de los otros sujetos y aquellas voces múltiples. Como afirma Quesada (1998) en su libro Uno y los otros: Nación y enajenación se confunden en este esfuerzo por elaborar un modelo metonímico del ser nacional que permita a todos los habitantes del territorio costarricense, pertenecientes a regiones geográficas relativamente aisladas, con formaciones étnicas, sociales y culturales heterogéneas, imaginarse como una unidad homogénea como un sujeto unitario desde cuyo centro se expresa una identidad común... (18).

\subsection{Consideraciones finales}

El domador de pulgas del escritor costarricense Max Jiménez es una novela que invita al lector o a la lectora a participar de una crítica. Es novela que instiga a replantear lo dicho sobre el ser costarricense; exhorta a mirar más allá de lo dicho y establecido. Es una novela que reclama la autenticidad de los individuos y sugiere despojarnos de prejuicios y de ideales ajenos a nuestra identidad latinoamericana.

Al mismo tiempo, se reconoce en la novela El domador de pulgas, una insistencia por parte de Jiménez de hurgar y encontrarnos en la soledad. Es decir, solo a partir de esta es cuando mejor nos escuchamos y nos hallamos. Una gran parte de sus candelillas (aforismos que nunca publicó en vida y que contienen una fuerte crítica a la sociedad de su época, así, como contenido filosófico) hablan de la satisfacción que produce la soledad cuando se trata de cavilar ya sea sobre nuestro ser u otras consideraciones. Él mismo aseveraba que: "cuesta mucho encontrarse en la soledad, pero es una gran victoria" (Citado por Quesada, 2004: 589). Por lo cual, muchos de los personajes pulguientos (como por ejemplo la pulga artista, el filósofo sexual, la pulga lírica, incluso el mismo domador) instan a vivir nuestros más íntimos pensamientos y respuestas en la compañía de la soledad. 
Hay que estimular el pensamiento, cuando todas aquellas contestaciones no sean suficientes. De ahí que en el capítulo que trata del amor de las pulgas, Jiménez plantea la necesidad de la palabra y la entrega al pensamiento. Para ello propone un diálogo, como los que escribía el filósofo griego Platón para abordar múltiples temas en su ya famosa obra homónima, Diálogos, con el fin, no de parodiar el idealismo platónico ${ }^{14}$ ya que no sentimos que sea la intención del autor, sino más bien exaltar lo que el mismo Jiménez llama: "La conversación pensada", siendo esta lo que más nos aleja de los animales.

En este capítulo, dicha glorificación versa sobre la importancia de la construcción del pensamiento a partir de la conversación inteligente. Diríamos pues, de la dialéctica, entendiendo por esta, el debate de tesis o ideas antagónicas; solas así se va construyendo un fino pensamiento a partir de la correlación de ideas. Aunque, también, Jiménez reconoce que en las conversaciones humanas, nada está garantizado: "el decir de algunas pulgas semejaba aullidos, o el verde cacareo de las loras" (49).

Este señalamiento adquiere mayor significado si comprendemos que en cuestiones de pensar pareciera que hay sujetos ( $\mathrm{y}$ a propósito del estado gregario del cual nos hace partícipe esta democracia) que consideran tediosa la tarea del cogitar, y les es

14 No concordamos con Mía Gallegos, cuando afirma en su artículo Un árbol llamado Max (páginas 41 y 42) que el capítulo que trata del amor de las pulgas sea una sátira al idealismo platónico. La poetisa costarricense asevera que es una parodia a los intelectuales que creían ostentar el conocimiento y la verdad. Haciendo una relectura de este capítulo, evidenciamos una exclamación al pensar y hablar con inteligencia. Y sobre todo, la contumacia, por buscarnos siempre en la soledad. más cómodo repetir ideas que concebirlas a base de un esfuerzo propio. Por el contrario, el capítulo que trata sobre el amor en las pulgas expresa, con entusiasmo, la importancia de "mover neuronas" con el único fin de enriquecer el ser. Así lo confirma el texto en estudio:

Y las pulgas discutían sin manifestaciones, porque creían en lo simple, no en los efectos, y la contradicción no perturbaba, sino que suavemente se confirmaban en las propias ideas, porque las pulgas buscaban la convergencia de las ideas, empezando aparte, ir hacia el punto. La conversación en la pulga siempre se supo era una fuerza, algo así como el vino, la música, el pensamiento (50).

Está claro, en este párrafo que Jiménez consideró participar de ideas como una de las herramientas para evitar ser presa de la simpleza. Los antagonismos fueron para este escritor motivos sinceros para la aproximación de los individuos; así, afirmó este: "todas nuestras actividades, aun las más opuestas, deberían reunirse en una finalidad para que no se pierdan" (Citado por Quesada 2004: 627). Esto es, concurrir con los otros en el diario pensar y conversar. Esta convocatoria, por parte de Jiménez, responde en gran medida, a una invitación a sus conciudadanos a que dejaran de lado el temperamento ovejuno. Y que emprendieran la búsqueda por sus propias respuestas, en lugar de esperar las de los demás. No obstante, hay un tipo de conversación a la que Max Jiménez manifiesta una cierta predilección: la soledad. 
Ya su pulga artista degustaba de semejante compañía. La pulga lírica crea en medio de la soledad, un hermoso poema. Dos personajes tan personales para nuestro escritor costarricense en los que él plasma parte de su pensamiento anacoreta.

En el desarrollo del capítulo que trata del amor entre las pulgas, se presenta un diálogo que versa sobre el amor. Naturalmente, estamos frente a una mímesis de la estructura que componían los ya famosos escritos del filósofo Platón. En esta ocasión (nos referimos al capítulo ya mencionado) un grupo de pulgas va apuntando lo que ellas consideran que es el amor ${ }^{15}$. Incluso las pulgas se dejan llevar por los temas y llegan al extremo de sentirse como en un banquete griego. Y transforman su entorno porque "las pulgas creían en el aspecto de las cosas, porque cultivaban la pintura, y hasta habían llegado a la deformación exterior para la formación interior, y se vestían de acuerdo con las conversaciones. Aquel día se vistieron de túnica y coturno" (51).

Pero volviendo al tema de la soledad, esta se proyecta como lema en la afluencia de ideas opuestas, a partir de las charlas que mantenemos en compañía de amigas, amigos, hermanos, hijos, padres o maestros. Incluso, aun necesitamos de la inexpresiva soledad, para adquirir nuestros mejores pensamientos $\mathrm{y}$, en última instancia, nuestras más peculiares resoluciones. Solo en ella se logra "estimular nuestras facultades" decía Jiménez (Citado por Quesada, 2004: 684). La soledad hace aflorar

15 Jiménez toma prestado el tema del amor del famoso Banquete de Platón, a fin de, recordarnos la pluralidad de realidades, así como las mil verdades a las que constantemente y a diario concurrimos. nuestros monólogos internos, y nos acercan más, con nuestro propio pensar y ser.

Quizá, esta conciencia de sensibilidad creadora a través de la soledad, se debe en parte a la indiferencia de la que fue objeto su obra artística y su persona.

El alto de una pulga que estaba sola, es un capítulo donde Jiménez continúa el tema de la introspección. Bajo este título, Jiménez nos presenta el instante, el breve lapso reflexivo de una pulga que estaba sola y alude a esa cotidianidad que nos atrapa y que se vuelve pesada. A las largas horas de espera llenas de incertidumbre, se añade el pensamiento sobre la indigencia de esperanza, el recuerdo por lo anteriormente vivido, por los amores lejanos y por el "inciertísimo mañana ${ }^{16}$ ".

Como el que va en una jornada y se detiene; quiere poner el faro abajo, y el impulso que fuerza a seguir una marcha de la cual no tenemos culpa ni conciencia.

Como la fiera que va por las veredas, de trote rítmico forzado, que en un instante levanta la cabeza, olfatea y parece cobrar conciencia de sí misma.

Como los barcos que rechinan y crujen, dentro de su misma marcha, parecen revelarse contra esa maldición de seguir adelante.

Como el sol que se nos va y deja un ocaso, como el pájaro seguro de que la rama es solo un alivio

16 Naturalmente esta frase hace alusión al tiempo de guerras que azotaba al siglo XX. Y, que producían zozobra en las personas ante el futuro de la humanidad. 
momentáneo; como el yo que se detiene en busca de consuelo; como los trenes que buscan desesperadamente las estaciones.

La forzosa conciencia de una marcha, en la cual vamos dejando, en lanzas y espinas invisibles, la energía para el inciertísimo mañana..." "...Y la vista se tiende, sondea, espera algo, que de llegar ya viene terminándose; así como todo lo que hemos pensado, como el acopio de las sensaciones; como ese cuerpo que con ser nada, ha sido todo, asilo de una vida, de una conciencia, y marcador terrible de la llegada de otros $(77,78)$.

Es muy interesante notar que la ilustración que Jiménez hace acompañar a este capítulo (el alto de una pulga que estaba sola) sea su propia versión de la famosa obra de Edvard Munch, El grito. Al igual que el pintor noruego, Jiménez, alude en la ilustración a la desesperación, el desánimo y el temor de un mundo que cambia a un ritmo inalcanzable y titubeante.

Así pues, lo escrito hasta aquí sobre la novela El domador de pulgas de Max Jiménez, no es más que un esfuerzo por preservar y conmemorar al escritor, al artista, al hombre y su legado. Más allá de ser una obra literaria, El domador de pulgas es y será siempre un escrito vigente y auténtico por la fuerza sincera de sus palabras, y porque aquellos pequeños y pulguientos personajes nos recuerdan lo imperfectos que somos como humanos; porque el relatofue escrito por un hombre convencido de que la humanidad muestra incapacidad de mirarse a sí misma. Su obra, y no solo la literaria, sería siempre un recordatorio de los falsos valores a los que nos hemos consagrado. $E l$ domador de pulgas es una novela que busca suscitar en el lector y la lectora (a partir de esos cuadros de historias pulguientas) que nuestra realidad no es ajena a nosotros, no es algo que se mira desde afuera, no es una representación vacía; todo lo contrario, la novela busca suscitar en una sociedad como la nuestra, tan llena de prejuicios y condicionada a respuestas autómatas, que es preciso ejercer de actores más que como meros espectadores. Explorar nuestra existencia, quitarnos el vendaje, mirar nuestros errores, entender que vivir nuestra libertad es más que elegir entre un helado de vainilla y uno de chocolate. Elegir es asumir. Entender que otros no pueden pensar por nosotros, nosotras la libertad es dudar, es preguntar, es voluntad de elegir, es transgredir, es responder. Como afirma Trejos en su ensayo Exploradores de la existencia. Max Jiménez y su "Domador de pulgas" (2006), esta es novela violenta porque "transgrede las normas de la humanidad que se cree ama del universo, que utiliza su legislación como una justificación, como venda para normalizar situaciones perversas y no ver sus errores" [s. p.]. De ahí su legitimidad en pleno siglo XXI.

\section{Conclusiones generales}

Afirmamos que el pensamiento filosófico no corresponde a una clase específica de ser humano, ya que todo individuo es, en cierto modo, un filósofo capaz de ser intérprete de su mundo y de su propia vida. Es decir, el pensamiento filosófico va más allá de una comprensión teórica y sistemática de ideas, pues abarca múltiples ámbitos 
del conocimiento y puede ser expresado de diferentes formas.

De esta manera, la concepción de filosofía de Max Jiménez responde a una visión crítica que es posible identificar en la obra $E l$ domador de pulgas. En ella, es posible realizar una lectura filosófica, no obstante que la obra responde al género novela, es decir se la puede leer filosóficamente, sin ser estrictamente un ensayo filosófico. Jiménez encuentra en el arte una epistemología para comprender e interpretar la realidad.

Jiménez, con su temperamento rebelde, atrevido y apasionado logró adentrarse en la filosofía buscando una interpretación personal del mundo y de la vida, como hombre de letras que se caracterizó por su pensamiento beligerante y crítico de la "Suiza centroamericana"

En la obra literaria, El domador de pulgas, se aborda una crítica a las conductas humanas y se evidencia una filosofía existencialista que se aleja de los sistemas lógicos-racionales, planteando a su vez una lectura filosófica que reflexiona sobre lo humano al juzgar críticamente la realidad en que uno está inmerso. Es decir, la filosofía en Jiménez es una constante indagación que nace en el ser humano en procura de responder a los más grandes cuestionamientos que emanan de él mismo.

Con respecto a la educación, Jiménez manifestó su disconformidad acusándola de convertirse en algo mecánico, que en vez de procurar la crítica y la libertad del ser humano, más bien busca fortalecer el "temperamento ovejuno" en las y los costarricenses, mediante el imaginario social. De ahí la necesidad de incorporar una pedagogía que contenga un sustento filosófico que logre responder a los desafíos de la época.

Es clara la insistencia del pensador por desmitificar nuestra estructura social y cultural, lo cual le valió el desprecio de sus coterráneos, quienes nunca supieron verse en sus críticas. Es incluso contradictorio conocer que si bien en nuestro país Jiménez fue criticado por los otros intelectuales de la época, fue ampliamente reconocido en el extranjero.

Es significativa, en este sentido, la inquietud planteada por la escritora costarricense Yolanda Oreamuno, otra rebelde e incomprendida intelectual nacional, quién señalaba el desconocimiento y el descrédito de las esferas costarricenses por la obra de Max Jiménez. Ciertamente, el pensador resultaba una figura desconcertante para la sociedad de la época, pero para los conocedores de su obra resulta claro que aún continúa cobrándosele caro sus críticas; a la fecha, no hay un premio con su nombre que conceda honor al trabajo de otros artistas y se estudia muy poco su pensamiento.

En nuestras escuelas se ha dejado de lado el análisis de sus obras narrativas. Es decir, Jiménez continúa resultando incómodo a la cultura oficial. De ahí nuestra insistencia para que su obra sea retomada y para hacer conciencia de la crítica de este pensador. Esto lo consideramos importante en particular para estas dormidas generaciones.

Milan Kundera ${ }^{17}$, en su obra $\mathrm{El}$ arte de la novela (1994)expresa que: "los artistas

17 Es un escritor de origen checo. Entre sus novelas más importantes se encuentran: La Insoportable levedad del ser, La broma y La vida está en otra parte. 
vanguardistas crearon obras, cierto es, realmente valientes, difíciles, provocadoras, abucheadas, pero las crearon con la certeza de que 'el espíritu del tiempo' estaba con ellos y que, mañana les daría la razón. (30)" Quienes nos hemos adentrado en el estudio de la obra narrativa y plástica de Max Jiménez, estamos conscientes de la labor provocadora de este pensador. Pero aquellos que han preferido seguir ignorándola, como se hizo a mediados del siglo XX, desconocen el mensaje que guarda: presentar nuestro pasado sin ornamentos, sin máscaras para mostrar de manera sencilla quiénes somos realmente. Quienes hemos tenido la audacia de adentrarnos en su obra sabemos mejor que nunca que el tiempo le dio la razón.

Coincidimos con el aporte crítico de Virginia Trejos Montero (2006) y su idea de que El domador de pulgas es una exploración de la existencia humana, la cual guarda un paralelismo con lo expuesto por Milan Kundera. Jiménez no solo nos narra una historia sobre un domador y sus pulgas, sino que se trata a grandes rasgos de una experiencia humana que se hizo novela.

Reconocemos aquí la gran labor que ha venido realizando Alfonso Chase para mantener vigente la obra de Max Jiménez y motivar a que se continúe estudiándola.

Asimismo, las dos compilaciones que realizó Álvaro Quesada Soto sobre la obra literaria de Max Jiménez, como también, la compilación Max Jiménez: aproximaciones críticas, que reúne una serie de ensayos de distintos escritores costarricenses, evocan el legado artístico de nuestro artista. Alabamos, igualmente, el trabajo de Ana Mercedes
González. Kreysa, Bernal Herrera, Carlos F. Monge, Virginia Trejos Montero, Carmen Naranjo, Mía Gallegos, Grethel Ramírez Villalobos, Gabriel Baltodano, Patricia Araujo, Ernesto Castegnaro, Flora Ovares, Margarita Rojas, Ivonne Robles Mohs y otras personas académicas estudiosas que han dedicado ensayos con el único objetivo de preservar el legado y mensaje de Max Jiménez.

No pretendemos que el nombre de Max Jiménez designe alguna avenida, plaza o biblioteca ni que se le erija una escultura que sirva de adorno en algún parque o institución pública del país. De todas formas, este tipo de reconocimiento termina teniendo un efecto vacío, de memoria muerta, en el colectivo de una nación que no reconoce a sus grandes artistas.

Nuestra cometido es diferente. Queremos honrar con palabras y hechos al hombre que a mediados del siglo anterior retó a la opinión pública. Al ser humano que manifestó su desacuerdo en diferentes formas artísticas, que desafió las artes mismas imprimiéndoles su estilo. Se le debe recordar en su pensamiento de carácter filosófico, examinar sus trabajos narrativos, apreciar que estos se prestan para discutir en una clase de filosofía. Comúnmente en nuestras aulas de filosofía, se tiene la idea-por parte de algunos docentes - de que esta es, solo y estrictamente, aquello escrito bajo sus parámetros. Nuestra investigación apunta y comprueba nuestra insistencia de la necesidad de extender esta visión de las fuentes para el estudio de la filosofía. 


\section{Bibliografía}

\section{Obras de Max Jiménez}

Jiménez, M. (1978). Candelillas . San José : Editorial Costa Rica.

Jiménez, M. (1999). El domador de pulgas. San José: Editorial Costa Rica .

Jiménez, M. (1997). El jaúl. San José: Editorial Costa Rica.

Jiménez, M. (1900). Sonaja. S. ed.

\section{Obras y ensayos sobre Max Jiménez}

Araujo, P. Max Jiménez: retrato de un rebelde. Repertorio Americano. Nueva Época, No 7, enero-junio de 1999.

Castegnaro, M. (1976). Max Jiménez Huete. La Nación, Suplemento Áncora, 3 de setiembre. San José.

Chase, A. (1982). Los campesinos en Max Jiménez . La República, 18 de julio, p. 7. San José.

Chase, A. (1994). Nuestro Max Jiménez. La Nación Suplemento Áncora, 29 de mayo.

Chase, A. (1973). Max Jiménez. Presentado por Alfonso Chase. San José: Ministerio de Cultura Juventud y Deportes.

Flores, J. C. (1986). Lo trunco en Max Jiménez. La Nación, 7 de febrero, p.2B. San José.

Gallegos, M. (2008). Un árbol llamado Max. Revista Nacional de Cultura, $\mathrm{N}^{\mathrm{o}} 56, \mathrm{p} .37-43$.

Fernández, V. H.. (1976) Max Jiménez visto por Yolanda Oreamuno. La Nación, 21 de diciembre, p. 2 B. San José.

La Nación. Recordando a Max Jiménez. 28 de mayo de 1987, p. 10. San José.

Loaiza, N. (1974). Max Jiménez. La Nación, 24 de marzo.
Macaya Lahmann, E. (1974). Surrealismo y romanticismo en la poesía de Max Jiménez. La República 10 de marzo. San José.

Naranjo, C. (1974). Obra de Max Jiménez. La Nación, 24 de marzo, pág. 15. San José.

Oreamuno, Y. (1964). Max Jiménez y los que están. Pórtico, Revista de la Editorial Costa Rica, enero-abril.

Quesada, Á. (1999). Max Jiménez. Aproximaciones críticas. San José: Editorial Universidad de Costa Rica.

Quesada, Á. (2004). Max Jiménez: obra literaria. San José: Editorial Universidad de Costa Rica (Colección Identidad Cultural).

Ramírez, G.(2005). La ironía y la poética de Max Jiménez: vanguardismo literario en Unos Fantoches. Tesis de licenciatura en literatura y lingüística con énfasis en español. Universidad Nacional de Costa Rica.

Ramírez, G. (2006). Max Jiménez: un retrato del artista moderno. Revista Comunicación, Vol.15, No 1 (Enero-julio), 63-69.

Robles, I. (1987). Max Jiménez y su ciclo lírico . La Nación, 16 de agosto, pág. 2-D.

Trejos Montero, V. (2006). Los exploradores de la existencia. Max Jiménez Huete y su Domador de Pulgas. Revista Tópicos del Humanismo. Heredia, Universidad Nacional, Escuelad de Filosofía.

\section{Bibliografía consultada}

Abbagnano, N. (1962). Introducción al existencialismo. Trad. José Gaos. 
Mexico: Editorial Fondo de Cultura Económica.

Bonilla, A. (1967). Historia de la literatura costarricense. San José: Editorial Costa Rica.

Botey, A. M. (2005). Costa Rica entre guerras: 1914-1940. San José: Editorial Universidad de Costa Rica.

Brenes Mesén, R. (1921). El misticismo como instrumento de investigación de la verdad. San José: J. García Monge. Camus, A. (1980). El mito de Sísifo. Trad. Luis Echávarri. Buenos Aires: Editorial Losada.

Cerutti, H. (2000). Filosofar desde nuestra América. Ensayo problematizador de su modus operandi . México: Miguel Angel Porrúa.

Durán, J. (2003). Senderos de identidad: diez ensayos sobre literatura costarricense. San José: Editorial Costa Rica.

Ferrater Mora, J. (1975). Diccionario de filosofía. Buenos Aires: Sudamericana.

Franco, J. (1985). La cultura moderna en América Latina . Mexico: Grijalbo.
Kierkegaard, S. (1982). El concepto de la angustia. Madrid: Editorial Espasa-Calpe.

Láscaris, C. (1975). Desarrollo de las ideas filosóficas en Costa Rica. San José: Editorial Costa Rica.

Martínez, E. (1967). En torno a Kafka y otros ensayos. Barcelona: Editorial Seix Barral.

Monge, C. F. (2005). El vanguardismo literario en Costa Rica. Heredia: Editorial Universidad Nacional (EUNA).

Mora, A. (1993). Historia del pensamiento costarricense. San José: EUNED.

Quesada, Á. (2008). Breve historia de la literatura costarricense. San José: Editorial Costa Rica.

Rojas, M. y Ovares, F. (1995). 100 años de literatura costarricense. San José: Ediciones FARBEN.

Sartre, J. P. (1997). El existencialismo es un humanismo. San José: Editorial Guayacán.

Savater, F. (1997). El valor de educar. Barcelona: Editorial Ariel.

Vincenzi, M. (1938). El hombre máquina. San José: Imprenta Lehmanm. 